\title{
Impacts of climate change on plant diseases-opinions and trends
}

\author{
Marco Pautasso • Thomas F. Döring • \\ Matteo Garbelotto • Lorenzo Pellis • Mike J. Jeger
}

Accepted: 5 January 2012

(C) KNPV 2012

\begin{abstract}
There has been a remarkable scientific output on the topic of how climate change is likely to affect plant diseases. This overview addresses the need for review of this burgeoning literature by summarizing opinions of previous reviews and trends in recent studies on the impacts of climate change on plant health. Sudden Oak Death is used as an introductory case study: Californian forests could become even more susceptible to this emerging plant disease, if spring precipitations will be accompanied by warmer temperatures, although
\end{abstract}

\author{
M. Pautasso $(\square)$ \\ Centre d'Ecologie Fonctionnelle et Evolutive (CEFE), \\ CNRS, \\ 34293 Montpellier, France \\ e-mail: marco.pautasso@cefe.cnrs.fr \\ T. F. Döring \\ The Organic Research Centre, \\ Hamstead Marshall RG20 0HR, UK \\ M. Garbelotto \\ Department of Environmental Science, Policy and \\ Management, Ecosystem Sciences Division, \\ University of California, \\ Berkeley, CA 94720, USA \\ L. Pellis \\ Department of Infectious Disease Epidemiology, \\ Imperial College London, \\ Norfolk Place, \\ London W2 1PG, UK \\ M. J. Jeger \\ Division of Biology, Imperial College London, \\ Silwood Park, \\ Ascot SL5 7PY, UK
}

climate shifts may also affect the current synchronicity between host cambium activity and pathogen colonization rate. A summary of observed and predicted climate changes, as well as of direct effects of climate change on pathosystems, is provided. Prediction and management of climate change effects on plant health are complicated by indirect effects and the interactions with global change drivers. Uncertainty in models of plant disease development under climate change calls for a diversity of management strategies, from more participatory approaches to interdisciplinary science. Involvement of stakeholders and scientists from outside plant pathology shows the importance of trade-offs, for example in the land-sharing vs. sparing debate. Further research is needed on climate change and plant health in mountain, boreal, Mediterranean and tropical regions, with multiple climate change factors and scenarios (including our responses to it, e.g. the assisted migration of plants), in relation to endophytes, viruses and mycorrhiza, using long-term and large-scale datasets and considering various plant disease control methods.

Keywords Adaptive ecosystem management - Biotic interactions · Landscape pathology P Phtophthora ramorum · Plant disease epidemiology · Tree fungal pathogens

Up to the 1990s, there was little information about climate change impacts on plant disease. For example, 
in a review on the impacts on plant health of increasing atmosphere concentrations of ozone, $\mathrm{SO}_{2}$ and $\mathrm{CO}_{2}$, Coakley (1995) stated that disease development may increase, decrease or remain stable depending on the particular pollutant and host-pathogen interaction. Similarly, Manning and von Tiedemann (1995) recognized that, at that time, there was limited knowledge about observed and predicted impacts of climate change on plant epidemics. However, plant pathologists already realized in the 1990s that climate change was clearly set to pose a challenge to many pathosystems. Referring to tree fungal pathogens, Lonsdale and Gibbs (1995) made the point that environmental change, especially when combined with pathogen and host introductions, may result in unprecedented effects. This statement has been re-iterated many times since (e.g. by Wingfield et al. 2010).

It is now recognized that climate change will affect plant diseases together with other components of global change, i.e. anthropogenic processes such as air, water and soil pollution, long-distance introduction of exotic species and urbanization (Gurr et al. 2011; Bradley et al. 2012; Matyssek et al. 2012; Régnière 2012). Predictions on how changes in climate will affect plant health at various spatio-temporal scales (from seasons to centuries, from the genetic to the ecosystem level, from farms to watersheds and entire continents) are based on: (i) already observed effects of climate change on plant diseases, (ii) extrapolation from expert knowledge and experimental studies, and (iii) computer models. It is widely acknowledged that climate change is likely to be pervasive across the planet, and will thus be relevant to most of the many existing (and yet to arise) plant health issues. Past reviews on the topic agree that climate change is a challenge that needs to be addressed together with the several problems already faced in agriculture, forestry, landscape management and nature conservation. It is important to study the interconnections among climate change and other drivers of global change in affecting plant health, also because declining plant health may result in climate change feedbacks (through changes in carbon sequestration and albedo patterns; O'Halloran et al. 2012).

Many reviews of the literature on plant diseases and climate change have recently appeared (Fig. 1), so that there is the need for an overview providing an update of this growing literature. Our focus is on plant pathosystems, but similar arguments can be made also for invertebrate pests. We start from (1) the case study of Phytophthora ramorum, provide (2) a summary of the main observed and forecasted climate changes, and describe (3) selected studies on the effect of single variables on the health of pathogens or plants. We then move to (4) indirect effects and interactions among global change factors, discuss (5) the issue of plant health predictability, modelling and extrapolation under climate change, and argue (6) that a diversity of
Fig. 1 Recent literature reviews on climate/global change and plant health (the figure was prepared in February 2011 and is not exhaustive, but merely illustrative; see reference list for bibliographic details)

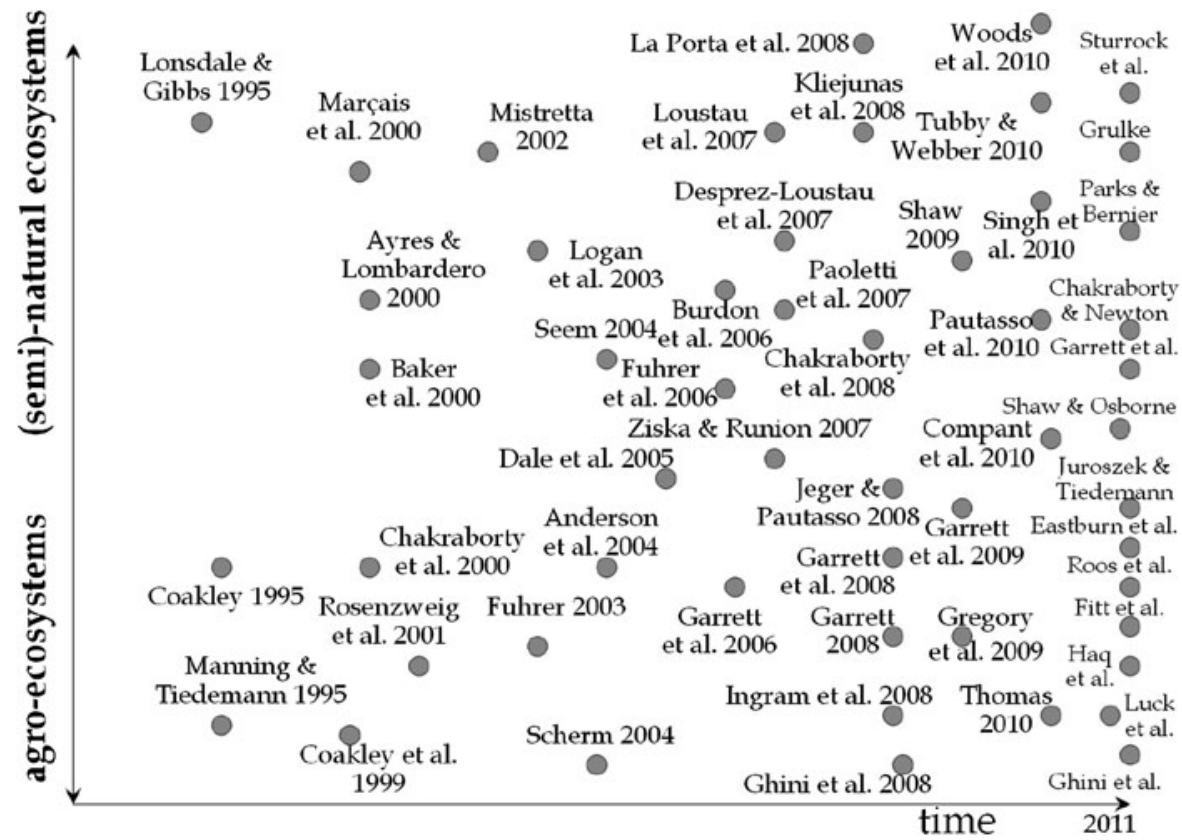


approaches is needed to make plant disease management more sustainable in the face of climate change. We also point out (7) the need for interdisciplinarity, stakeholder involvement and consideration of trade-offs, introduce (8) the debate on land-sparing vs. -sharing in the context of climate change effects on plant health, and conclude with (9) some take-home messages and research opportunities. There are many other aspects relevant to the issue of climate changes and plant health, but we believe that the selected topics can provide a good point of entry into the relevant literature.

\section{A case study: climate change and Phytophthora ramorum}

Although there is still uncertainty about the direction of change for many regions (Shaw and Osborne 2011), climate change is expected to be omnipresent. It is thus likely to affect most plant pathosystems, included those that are already troublesome or out of control under current climate conditions. As an example, take Sudden Oak Death, caused by the generalist oomycete Phytophthora ramorum (Rizzo et al. 2011). The pathogen is a newly introduced invasive species in the USA and Europe and currently causes large-scale mortality in a range of tree and shrub species in California. Climate change could make forests on the West Coast of the USA even more susceptible to this pathogen, in case of warmer temperatures during spring precipitations (Venette 2009). P. ramorum-inoculated branch cuttings of coast live oaks (Quercus agrifolia) developed larger lesions in spring, a result interpreted to suggest a role of synchronicity between host cambium activity and pathogen colonization rate (Dodd et al. 2008). Such co-occurrences between host phenology and pathogen sporulation are likely to be affected by climate shifts (Donnelly et al. 2011).

At the same time, climate change may modify the pattern of susceptibility to $P$. ramorum in ecosystems not currently affected but at risk due to the presence of potentially sporulating hosts (e.g. plantations of Japanese larch, Larix kaempferi), from the Appalachians to the Mediterranean, from New Zealand to Japan (Brasier and Webber 2010; Tubby and Webber 2010). Even if the change in climate may turn out not to be favourable everywhere to $P$. ramorum, e.g. because of a lower amount of precipitation during the period of main activity of the pathogen, there could still be negative consequences for plant health. Such negative impacts of climate change can be expected when a mismatch between plants and their environment leads to an increased vulnerability to biotic agents (Ayres and Lombardero 2000; Lonsdale and Gibbs 2002). Therefore, there is today little doubt that future ecosystems will experience altered disturbance patterns and that, in general, new plant health problems will become more frequent (Marçais et al. 2000).

\section{A summary of observed and predicted climate changes}

It is useful to summarize current knowledge on climate change before moving to the main potential effects of climate change on plant pathosystems. For example, Chakraborty et al. (2008) remind us that the current $\mathrm{CO}_{2}$ concentration in the atmosphere $\left(\left[\mathrm{CO}_{2}\right]\right.$, which is set to exceed $400 \mathrm{ppm}$ in a few years) is higher than the range of concentrations (180-300 ppm) measured from ice cores going back 650,000 years. The main causes of this global $\left[\mathrm{CO}_{2}\right]$ increase are fossil fuel burning and land-use changes (mainly deforestation) (Cerri et al. 2007; Paterson and Lima 2010). The increase in $\left[\mathrm{CO}_{2}\right]$ and the concentration of other greenhouse gases has already resulted in an increase in the global average temperature of $0.6-0.7^{\circ} \mathrm{C}$ over the last century (Mann et al. 1998; Walther et al. 2002; Benvenuti 2009). This average increase has been translated in a trend in many regions towards shorter and warmer winters (Quarles 2007). There is widespread evidence that such seasonal shifts have already affected the phenology, abundance and distribution of many species (Körner and Basler 2010; Matesanz et al. 2010).

The documented evidence of recent climate changes is dwarfed by the magnitude of the forecasted further shifts during the 21 st century and beyond (with a best estimate of +2 to $4^{\circ} \mathrm{C}$ in global average temperatures by the end of the century; Milad et al. 2011). Some ecoregions will be more affected than others by climate changes (Engler et al. 2011; Heyder et al. 2011; Teixeira et al. 2012), with the most biodiverse ecoregions particularly at risk (Beaumont et al. 2011). In Europe, Southern regions are predicted to be more sensitive to climate change than Northern ones, due to increases in summer drought (Kůdela 2009). In North America, the temperature increase is expected to be greater than the global average, particularly in boreal and mountainous regions (Bentz et al. 2010). Although 
tropical regions are predicted to experience a lower absolute increase in temperatures, tropical metabolic rates are likely to be affected more strongly than at extra-tropical latitudes, given the non-linear influence of temperature on metabolic rates (Dillon et al. 2010). Metabolic rates are key determinants also of the activity of plant pathogens. Many tropical crops show yield reductions in the presence of warmer temperatures, as current temperatures are already close to the maximum physiological limit (Cerri et al. 2007). Also relevant to plant health is the forecasted increase in extreme weather events, from floods to drought, from heat waves to severe wind, rain, and hail storms (Boland et al. 2004; Hegerl et al. 2011; Peng et al. 2011): floods can make the spread of water-borne pathogens easier, droughts and heat waves can predispose plants to infection, storms can enhance wind-borne dispersal of spores.

\section{Direct effects of climate change on plant pathosystems}

Plant pathologists have long considered environmental influences in their study of plant diseases: the classic disease triangle emphasizes the interactions between plant hosts, pathogens and environment in causing disease (Garrett 2008; Klopfenstein et al. 2009; Grulke 2011). Climate change is just one of the many ways in which the environment can move in the long term from disease-suppressive to disease-conducive or vice versa (Baker et al. 2000; Fuhrer 2003; Truscott and Gilligan 2003; Perkins et al. 2011). Therefore, plant diseases could be even used as indicators of climate change (Logan et al. 2003; Garrett et al. 2009), although there may be other bio-indicators which are easier to monitor. Long-term datasets on plant disease development under changing environmental conditions are rare (Scherm 2004), but, when available, can demonstrate the key importance of environmental change for plant health (Jeger and Pautasso 2008; Fabre et al. 2011). For example, analysis of archive samples from the Rothamsted long-term $\left(1850 \mathrm{~s}^{-}\right)$wheat production and fertilizer experiment shows that historical records of $\mathrm{SO}_{2}$ emissions are well correlated with the ratio of two pathogens (Phaeosphaeria nodorum/Mycosphaerella graminicola) (Bearchell et al. 2005; Fitt et al. 2011).

Plant health is predicted to generally suffer under climate change through a variety of mechanisms, from accelerated pathogen evolution and shorter incubation periods to enhanced abiotic stress due to mismatches between ecosystems and their climate and the more frequent occurrence of extreme weather events (Chakraborty and Datta 2003; Chakraborty 2005; Chakraborty et al. 2011; Ghini et al. 2011b; Newton et al. 2011; Sutherst et al. 2011). Drought is expected to lead to increased frequency of tree pathogens, mainly through indirect effects on host physiology (DesprezLoustau et al. 2006). Drier conditions may also have direct effects on pathogens, as shown by the invasive exotic species Heterobasidion irregulare in central Italy, which appears better adapted to dispersal in the Mediterranean climate than the native $H$. annosum species (Garbelotto et al. 2010). Reduction in frost due to increased average minimum temperatures implies the removal of a limiting factor for pathogens such as Fusarium circinatum (the causal agent of pine pitch canker), with consequent enlargement of the area at risk, particularly in Europe (Watt et al. 2011). Conversely, for pathogens that take advantage of frost-wounds in order to infect the host (e.g. Seiridium cardinale on cypress species), a decreased occurrence of frost could lead to reduction in disease incidence (Garbelotto 2008). In the case of insect-vectored diseases: if warmer temperatures translate into additional insect generations (as they often do), obviously this will increase transmission rates of the invasive pathogen (Dobson 2009; Robinet et al. 2011).

Already observed climate warming appears to have been associated with shifts in plant hosts for some fungi (Gange et al. 2011). Some regional consequences of climate change on plant health are already present: for example, although changes in cropping practices may also be playing a role, there have been progressively earlier and more frequent observations of Phytophthora infestans in Finland (Hannukkala et al. 2007). In forests of Canada and the Western USA, warmer temperatures have been associated with large-scale outbreaks of bark beetles (Bentz et al. 2010; Woods et al. 2010; Woods 2011). Plant pests are already causing substantial crop losses in most regions of the world (Rosenzweig et al. 2001; Barnes et al. 2010; Haq et al. 2011). An increase in extreme weather events and a trend towards warmer temperatures may well worsen these impacts (Roos et al. 2010; Thomas 2010; Hakala et al. 2011; Madgwick et al. 2011; West et al. 2012). Regional tree declines due to drought, new pathogens and existing pests, and the interactions between these factors, can have negative repercussions on biodiversity (Fischer et al. 2010; Parks and Bernier 2010; Tomback and Achuff 2010; Carnicer 
et al. 2011; McDowell et al. 2011). However, they can also in some cases help increase the supply of deadwood across forests, where management has resulted in a decline of this important requirement for biodiversity conservation (Calder and Kirkpatrick 2008; Lonsdale et al. 2008; Cobb et al. 2012).

Climate change is indeed not only going to threaten plant health, but may in some cases enhance it. For example, in Scotland, models predict in the mid-term a lower impact of oilseed rape diseases such as Leptosphaeria maculans and Pyrenopeziza brassicae (Fitt et al. 2011). In Northern Germany, however, oil seed rape pathogens such as Alternaria brassicae, Sclerotinia sclerotiorum, and Verticillium longisporum are predicted to be favoured by average warmer temperatures, particularly when taking a long-term (2071-2100) view (Siebold and von Tiedemann 2012). Warmer climates and more frequent extreme events are likely to increase the magnitude of forest fires, which could act as purging factor for some diseases in woodland. Nonetheless, in many cases an increased frequency and severity of fires can decrease the ability of forests to provide goods and services (Sturrock et al. 2011). It is also possible that warmer temperatures may make it easier to deploy biological control in some cases, although there is still little available information on the impacts of climate change on plant disease biological control (Ghini et al. 2008; Compant et al. 2010).

\section{Interactions among global change factors}

Direct effects on plant health of climate warming, increased pollutants and $\mathrm{CO}_{2}$ concentrations (Kliejunas et al. 2008; McElrone et al. 2010; Davies et al. 2011; Eastburn et al. 2011) will be accompanied by the easier introduction of exotic invasive species (Chakraborty et al. 2000; Lonsdale and Gibbs 2002; Ganley et al. 2011; Chytrý et al. 2012). Introductions of novel plant pathogens have already occurred in many regions (Brown and Hovmøller 2002; Dehnen-Schmutz et al. 2010; Stenlid et al. 2011; Fig. 2), but climate changes are likely to often facilitate their further establishment and spread (Anderson et al. 2004; Shaw 2009; Hannukkala 2011). There is a consensus that prediction and management of climate change effects on plant health are complicated by interactions between globalization, shifts in climate, pollution and increasing numbers of invasive plants,
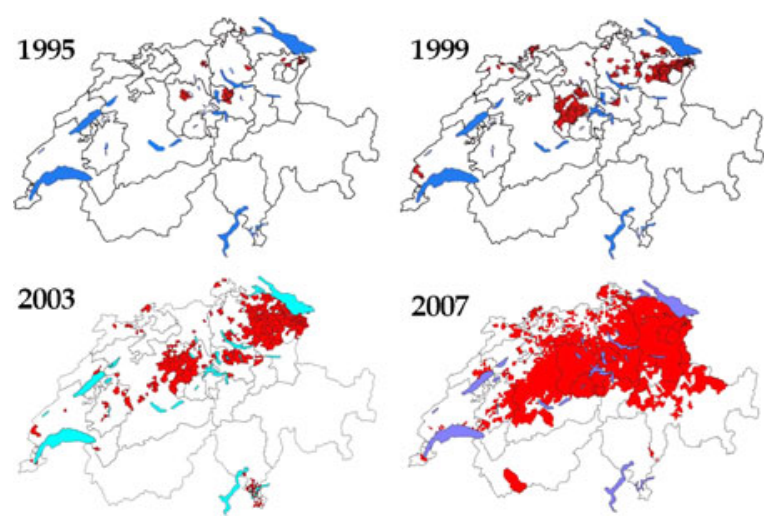

Fig. 2 Development of the fire blight epidemic (due to the bacterium Erwinia amylovora) in Switzerland, 1995-2007. The pathogen was introduced into Switzerland from SouthWest Germany in the 1980s (this explains why the climatically more suitable Ticino has been less affected by fire blight than northern Swiss Cantons). It affects tree and shrub species of the family Rosaceae (e.g. Malus, Pyrus, Crataegus) and is favoured by humid and mild springs, as was the case in 2007, when the epidemic reached unprecedented levels (from Holdenrieder et al. 2008)

pests and pathogens (Mistretta 2002; DesprezLoustau et al. 2007a; Danon et al. 2011; Fig. 3).

Ensuring that landscape management incorporates the many insights from new studies on global change impacts on plant health will be important to improve the sustainability and security of food production, and to make biodiversity conservation more successful (Dale et al. 2005; Fletcher et al. 2009; Pautasso et al. 2010; Geyer et al. 2011). Assessing the ecological consequences of climate change requires an understanding of biotic interactions (Tylianakis et al. 2008; Médiène et al. 2011), including the evolution of plant pathogens and their hosts at the interface between fields and surrounding remnant semi-natural ecosystems (Burdon and Thrall 2008). Although some studies of multiple global change factors are appearing (e.g. Matesanz et al. 2009; Baeten et al. 2010), these analyses have rarely involved plant pathogens (e.g. Phytophthora citricola on Fagus sylvatica seedlings under elevated $\mathrm{CO}_{2}$ and $\mathrm{N}$ fertilization; Fleischmann et al. 2010). Free-Air $\mathrm{CO}_{2}$ Enrichment (FACE) facilities can deliver useful insights on how plant pathosystems are likely to be affected by the interactions among global change factors (Eastburn et al. 2009, 2011). There is a need to include in such studies various plant disease management approaches, including 


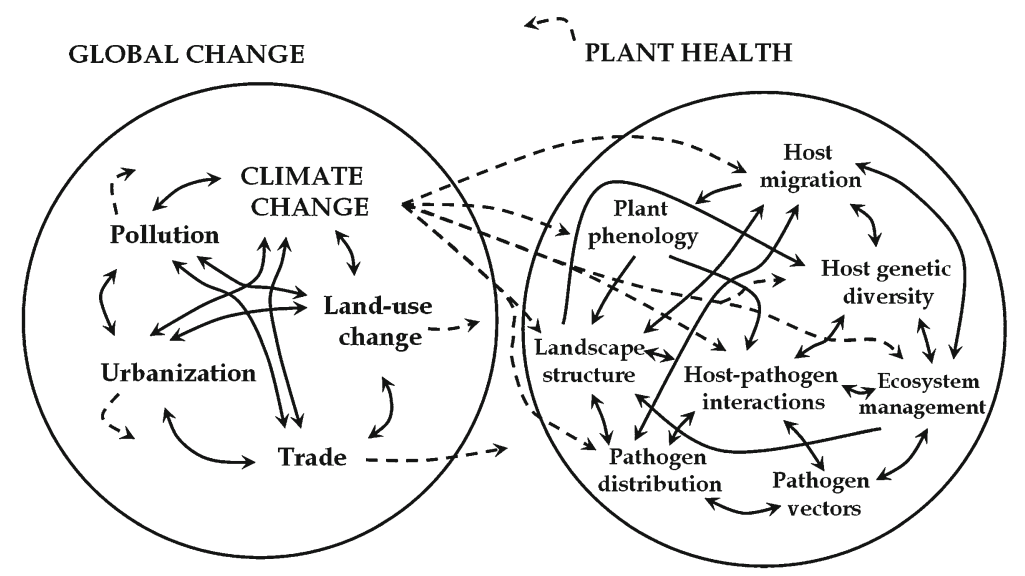

Fig. 3 Global change impacts on plant health. Global change is composed of the interactions of various drivers (climate change, increased trade, land-use change, pollution, urbanization). All these factors will have an impact on plant health, through direct effects on host-pathogen interactions, and via indirect effects on host migration, genetic diversity and phenology, as well as on

organic agriculture (Crowder et al. 2010), biocontrol mixtures (Xu et al. 2011), and the design of agricultural landscapes for natural pest control (Steingröver et al. 2010).

\section{Predictability, modelling and extrapolation}

The many factors involved in determining plant health under a changing climate, their direct and indirect effects, interactions and feedback loops raise the question of whether a predictive understanding of these complex systems is achievable (Garrett et al. 2011). Predictability is a key condition to the design of solutions to the many new plant health problems likely to arise, or to old problems becoming more severe. Many reviews available on the topic of plant diseases and climate change agree that there is a need for more empirical data on the subject (Loustau et al. 2007; Ziska and Runion 2007; Chakraborty et al. 2008; Ingram et al. 2008; Chakraborty and Newton 2011; Luck et al. 2011). The assumption is that more and better data will make prediction more accurate and/or reliable (Shaw and Osborne 2011). In these efforts, documented impacts of environmental change on plant pathosystems need to be complemented by predictions based on expert knowledge and common sense (Marçais and Desprez-Loustau 2007; Roos et al. 2010) as well as on computer simulations (Bergot et al. 2004; Desprez- disease distribution, insect pests, vectors and landscape structure. There is a feedback from plant health to global change. To be successful in the face of global change, ecosystem management will have to consider this complexity of interactions (modified from Pautasso 2012)

Loustau et al. 2007b; La Porta et al. 2008; Watt et al. 2010; Seidl et al. 2011).

For example, according to models, predicted climate change will have different effects on phoma stem canker (Leptosphaeria maculans) on oilseed rape in the north and south of the UK (Butterworth et al. 2010). Although there is still a challenge in extrapolating from individual studies to epidemics over entire regions (Burdon et al. 2006; Garrett et al. 2006), the phoma study shows that statements about regional patterns in future disease development under climate change are possible. Nonetheless, their direct test in reality will have to wait. There is an increased appreciation that understanding of the interactions among weather and the spatial distribution of susceptible/resistant host patches are keys to managing plant diseases across entire landscapes (Seem 2004; Skelsey et al. 2010). The integration of multi-scale epidemic simulations with climate change scenarios is indeed one of the outstanding challenges in landscape epidemiology (Holdenrieder et al. 2004; Pinkard et al. 2010).

Despite these advances in the understanding of the interactions between pathosystems and a changing climate, it is important to make clear the inherent uncertainty in models of plant disease development under climate change. The prediction from climate research that climate is going to be more variable, i.e. less predictable, is matched by the motto of plant pathologists involved with exotic organisms ("expect 
the unexpected"; Webber 2010). What is needed in such paradoxical and idiosyncratic situations, in addition to continuing research into the biological mechanisms underlying plant health under novel conditions, is the development of agricultural and forestry systems that can cope with change. This is not impossible. Even if - due to our limitations in data availability, epidemiological understanding, funding, time, computing power, and knowledge of future climate - we are unable to predict the trajectory of each pathosystem under climate change accurately, some general guidelines for action can be identified. For example, there is agreement that adaptive management is an important strategy to develop, because of its in-built monitoring and iterative learning process (Yousefpour et al. 2012). Similarly important is the development of a range of different predictive techniques, so as to be able to take advantage of a diversity of analytical approaches. Equally, the greater integration of plant diversity in production systems is expected to buffer against the unpredicted or unpredictable alterations that pathosystems will experience in a changing climate (Østergård et al. 2009; Brummer et al. 2011; Döring et al. 2011; Jarvis et al. 2011).

\section{Plant health management strategies: diversity is needed}

As a consequence of all these potential impacts of climate change on the health of plants and their associated organisms, there is increasing recognition that we need to develop strategies for long-term adaptation and insurance in agriculture and silviculture (Fuhrer et al. 2006; Ciscar et al. 2011). The importance of adaptive management is also stressed from the point of view of North American forest management by Millar et al. (2007), who point out that future climate change challenges will not be met by a single solution, but by a mix of different approaches adapted to different situations. As an example (for an invasive pathogen under current climate), whilst there has been an effort at eradication of the single $P$. ramorum outbreak in Oregon forests, the similarly isolated Humboldt county outbreak in Northern California was left to follow its course, so that now we have a rough idea (without replication) of the likely medium-term outcomes of both approaches. Even if developing landscape-scale experiments remains a challenge (even more so when considering climate change), such an approach is essential to validate models and risk analysis (Körner 2003; Petter et al. 2010; Venette et al. 2010). The spread of invasive plant diseases in regions of naive host populations (i.e. with no history of co-evolution) is a likely outcome of climate warming and calls for increased monitoring and modelling (Loustau et al. 2007; Moricca and Ragazzi 2009). In their international overview, Ogden and Innes (2007) agree, but deplore the lack of action so far, inasmuch as climate considerations have been rarely adopted by forest managers in strategic and operational plans yet.

Wherever pathosystems are already difficult to deal with, it is to be expected that climate change will make the opportunities for sustainable disease management even more remote (Coakley et al. 1999). In this case, diversification alone will not be adequate without the support of the whole range of current and novel management approaches. For example, according to models taking into account climate change, it has been suggested that it may become necessary to increase the number of fungicide treatments against Plasmopara viticola in wine-producing regions of Northern Italy over the next decades (Salinari et al. 2006). However, an increase of extension activities that prevent abuse and misuse of pesticides should also be considered (Savary et al. 2011b). The current reliance on economically attractive management approaches may well be challenged in the future, not just because of climate change, but also due to developments in society, for example an enhanced awareness of environmental issues, see e.g. the new pesticide regulations due to enter in force in the European Community (Erlacher and Wang 2011; Mills et al. 2011). Moreover, preventive measures such as the use of cultivar mixtures in fields and the preservation of tree species diversity in forests are still likely to make sense also in the presence of novel climates (Finckh and Wolfe 1996; Garrett and Mundt 1999; Zhu et al. 2000; Pautasso et al. 2005; Bodin and Wiman 2007; Keesing et al. 2010; Quijas et al. 2010; Juroszek and von Tiedemann 2011). In addition, new approaches will be needed, from pest risk assessments including climate change and economic considerations (Yemshanov et al. 2009), to involvement of the stakeholders for a certain plant pathosystem in the development of strategies to cope with the disease (for $P$. ramorum without considering climate change, Alexander and Lee 2010), from spatio-temporal analysis of known occurrences of a plant pathogen in the plant trade and the semi-natural environment ( $\mathrm{Xu}$ et al. 2009) to the use of network theory tools in targeting control and predicting 
climate change impacts (Araújo et al. 2011; Chadès et al. 2011; Moslonka-Lefebvre et al. 2011). Innovative approaches in plant disease management will be required also given the likely increased importance of novel agroecosystems (e.g. biofuel crops: Fitt 2011; Newton et al. 2011).

\section{Interdisciplinarity, stakeholder involvement and trade-offs}

One problem here is that climate and global change will not act on plant health in isolation, but in addition to other worldwide processes, from dwindling fossil energy sources to a still growing global human population, from sea-level rise to freshwater scarcity, from attempts to improve food safety/security to those trying to arrest biodiversity loss/homogenization (Gregory et al. 2009; Flood 2010; Chimera et al. 2010; Kulakowski et al. 2011; Reganold et al. 2011; Savary et al. 2011b). Multiple, interconnected processes such as these will require interdisciplinary science, long-term funding and the increased use of meta-analysis (e.g. Zvereva and Kozlov 2006; Blankinship et al. 2011; Fischer et al. 2011; Kozlov and Zvereva 2011; Rohr et al. 2011). At the same time, there is a need for the evolution of plant health regulatory frameworks to catch up with the latest scientific developments, from taxonomic advancements (e.g. the identification of novel Phytophthora species: Jung et al. 2011; Vettraino et al. 2011) to network epidemiology (Jeger et al. 2007; Keller et al. 2011) and digital pest diagnostics and severity estimation (Bock et al. 2010; Norton and Taylor 2010). The involvement of the many stakeholders in plant health (Furstenau et al. 2007; Macleod et al. 2010) deserves repetition in more than one section of this review, as it can be beneficial not just to adapt the regulatory framework, but also to improve dissemination of plant health knowledge (Jacobi et al. 2011; Rebaudo and Dangles 2011) and to devise effective response strategies to new invasive pathogens (Crall et al. 2010).

For example, citizen-science can help in the identification of host resistance in selected locations or throughout distributional ranges (Ingwell and Preisser 2011). According to a recent participatory process, 'finding the most technically and financially effective ways of identifying, monitoring and controlling invasive species, pests and disease' is one of the top policy-relevant research questions in the UK forestry sector (Petrokofsky et al. 2010). This aim is complicated by concurrent objectives in biodiversity conservation. For instance, habitat fragmentation is often considered to affect in a negative way meta-populations of species of conservation interest, but could make dispersal of plant pathogens more difficult across the shifting distributional ranges of their old and new hosts (Margosian et al. 2009), unless long-distance links are provided by plant trade (Harwood et al. 2009). This kind of trade-offs makes it important to involve economists in the formulation of plant health policy under uncertainty (Horan and Lupi 2010; Ndeffo Mbah et al. 2010; Moore et al. 2010; Bradford and D'Amato 2012).

\section{Plant health and climate change: land sparing or sharing?}

Cross-talk between plant health policy-makers, the publics and economists will need not only to involve scientists active in pest surveillance and monitoring, as well as epidemic analysis and modeling, but also those from outside plant pathology (Fig. 4). For example, in biodiversity conservation there is currently a debate on how best to meet the additional food needs due to the growing human population and changing dietary habits of many countries without jeopardizing biodiversity conservation efforts. On the one hand, increasing the intensity of cultivation may make it possible to save some natural ecosystems from conversion into cropland (land sparing). On the other hand, decreasing the intensity of cultivation may enable the coexistence of biodiversity and crops in agro-ecosystems, but would allow remnant patches of natural ecosystems to shrink (land sharing) (Ewers et al. 2009; Clough et al. 2011; Lambin and Meyfroidt 2011; Lin 2011; Phalan et al. 2011; Fitter 2012). Little attention has been paid to how this issue will be influenced by the effects of climate change on plant health, or whether one or the other strategy is more advisable to better cope with such effects (Jones 2009; Jeger et al. 2011; Savary et al. 2011b). Land sharing between food production and biodiversity conservation has the advantage of a more diverse composition of croplands, which would make them more adaptable to new conditions. At the same time, this strategy may make (semi)-natural ecosystems and their plant health more vulnerable to climate change, due to the lower size, quality and connectivity of habitat patches. Conversely, land sparing may increase the 
Fig. 4 Network of interactions among experts (circles), economists (triangles), publics (diamonds) and policy makers (rectangles) in the plant health governance landscape. For a successful management of plant health problems in a changing environment, there is need for better information flow among the components of this network. Modified from Mills et al. (2011)

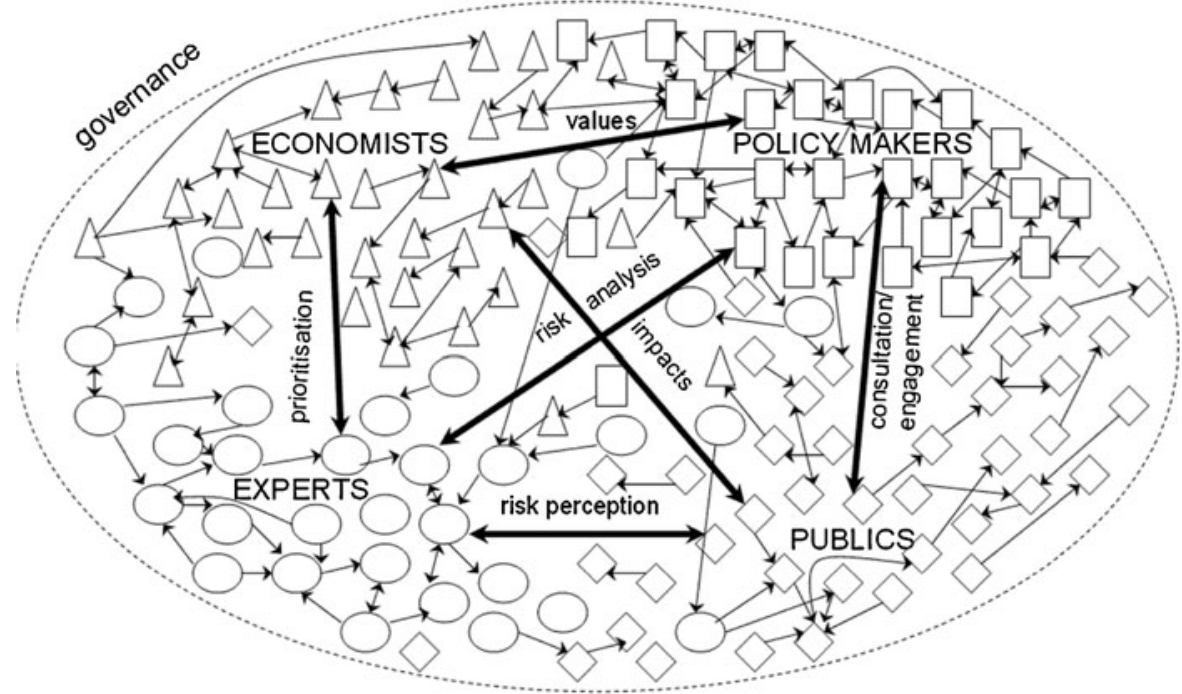

chances of adaptation in semi-natural forest, woodland, scrubland and grassland, but may result in more pronounced plant health problems in intensively managed ecosystems. Although this issue is often presented in terms of a dichotomy, a diversity of strategies may be a good way to proceed also in this case, also given the continuum between intensive cultivation and pristine ecosystems. Nonetheless, the land-sharing vs. sparing debate may benefit from incorporating both climate change and plant health considerations.

Similarly, both the land-sparing vs -sharing debate and the many contributions to how to improve plant health management under climate change will need to recognize the importance of soil health, both in terms of its function as habitat for soil-borne plant pathogens, and in relation to the multiple roles of soil microbes in promoting plant health and productivity (French et al. 2009; Singh et al. 2010). There is a consensus that we have currently less knowledge about potential impacts of climate change on soil-borne pathogens compared to foliar pathogens (Eastburn et al. 2011). Progress in our understanding of how both groups of plant pathogens will respond to climate change will be facilitated by the application of emerging genetic techniques (Pritchard 2011). Genetic analyses will be instrumental in devising strategies to cope with an increased pressure from established and new diseases as a result of better suitability of the climatic conditions and/or more intense and farreaching trade (Bawa and Dayanandan 1998; Archie et al. 2008; Jombart et al. 2011). For example, there is genetic evidence that some ash trees (Fraxinus excelsior) in Denmark are resistant against the emerging fungal pathogen Chalara fraxinea (McKinney et al. 2011; Kjær et al. 2012), which is now reported to cause ash dieback throughout Europe, from Poland to France and from Sweden to Switzerland (Bengtsson et al. 2012; Gross et al. 2012). For this pathosystem, there are also data on the genetic variability of the pathogen in lowland vs. highland Poland (Kraj et al. 2012) and in the Åland islands, mainland Finland, Estonia and Latvia (Rytkönen et al. 2011). Although there is increasing attention to the patterns in species genetic diversity across landscapes and distributional ranges (including studies of plant fungal pathogens, e.g. Barrès et al. 2008; Baumgartner et al. 2010; Dutech et al. 2010; King et al. 2010; Dale et al. 2011; De Simone et al. 2011; Tsui et al. 2012), there is still little inclusion of such important data in models predicting climate change impacts on plant health, as well as in studies of the land-sparing vs. -sharing issue.

\section{Plant health and climate change: conclusions and research gaps}

Climate change effects on plant health are likely to be ubiquitous, both in terms of direct and indirect impacts. Maintaining plant health across the planet, in turn, is a key requirement for climate change mitigation, as well as the conservation of biodiversity and the provision of ecosystem services under global change. Since there are inherent limits in our understanding of plant pathosystems and their interactions with future climates, it is likely 
that a diversity of management strategies, including learning from our mistakes, is a better choice than a single, inflexible solution. As an exception, adding diversity to our fields, plantations, forests, and landscapes appears as a commendable insurance policy which may increase the adaptation potential of a range of managed ecosystems. To maintain ecosystem health and services under variable, unpredictable or unknown conditions, we need more resilient systems, decentralization, participatory research and breeding networks. At the same time, increased involvement of the many stakeholders and scientists from outside plant pathology shows the importance of considering trade-offs with other objectives. Increasing diversity would be in favour of a land-sharing approach, but may be relevant also to land-sparing scenarios (e.g. at the margin of fields), depending on the spatial and temporal scale and the type of diversity (genetic, species, species turnover, ecosystem) considered. Within and beyond the European level, there is certainly the scope to integrate plant health considerations into agri-environment schemes, biosecurity regulation, and research across the network of the world's botanic gardens (Britton et al. 2010; Golding et al. 2010; Webber 2010).

Research gaps in this rapidly developing area include effects of climate change on plant pathosystems:

- of mountain and boreal ecosystems (Roy et al. 2004; Rohrs-Richey et al. 2011; Witzell et al. 2011);

- of Mediterranean and tropical regions (Garbelotto 2008; Zocca et al. 2008; Thompson et al. 2010; Savary et al. 2011a, b);

- with climate change aspects other than temperature (e.g. precipitation: Hawkes et al. 2011);

- with multiple climate change factors (Paajanen et al. 2011);

- in relation to endophytes and viruses, two key factors for plant health (Jones 2009; Brosi et al. 2010);

- in relation to mycorrhiza diversity and productivity (Deslippe et al. 2010; Egli 2011);

- with long-term datasets (Hannukkala et al. 2007; Fitt et al. 2011);

- under various climate change scenarios (Watt et al. 2011);

- following various climate change management options (e.g. assisted migration of plant species; McDonald-Madden et al. 2011; Garbelotto and Pautasso 2012);
- and considering various plant disease control methods (Ghini et al. 2011a).

More research on the role of feedbacks is needed too (Paoletti et al. 2007; Garrett et al. 2011): not only will climate change affect plant health, but a regionally-toglobally declining plant health may in turn accelerate climate change because of the additional carbon emissions due to increased plant mortality and soil organic matter mineralization, so that plant disease management, by maintaining plant health, has a role in reducing and preventing greenhouse gas emissions (Mahmuti et al. 2009; Lovett et al. 2010; Busby and Canham 2011; but see Bernier et al. 2011). Most importantly, research on climate change and plant health needs to reflect the variety of levels affected and the many viewpoints involved and tools available, from the molecular to the landscape scale, using network theory, meta- and risk analysis, in collaboration with various stakeholders, the publics and scientists outside plant health science.

Acknowledgements Many thanks to K. Dehnen-Schmutz, T. Harwood, O. Holdenrieder, A. MacLeod, P. Mills, M. MoslonkaLefebvre, M. Shaw, J. Webber, M. Wolfe and X. Xu for insights and discussions, and to T. Matoni and anonymous reviewers for helpful comments on a previous draft. This review was partly funded by the Rural Economy and Land Use Programme (RELU), UK, and by the French Foundation for Research on Biodiversity (FRB) and is partly based on a presentation at the Climate Change and Plant Disease Management Conference, University of Evora, Portugal, 10-12 November 2010.

\section{References}

Alexander, J., \& Lee, C. A. (2010). Lessons learned from a decade of Sudden Oak Death in California: evaluating local management. Environmental Management, 46, 315-328. doi:10.1007/s00267-010-9512-4.

Anderson, P. K., Cunningham, A. A., Patel, N. G., Morales, F. J., Epstein, P. R., \& Daszak, P. (2004). Emerging infectious diseases of plants: pathogen pollution, climate change and agrotechnology drivers. Trends in Ecology \& Evolution, 19, 535-544. doi:10.1016/j.tree.2004.07.021.

Araújo, M. B., Rozenfeld, A., Rahbek, C., \& Marquet, P. A. (2011). Using species co-occurrence networks to assess the impacts of climate change. Ecography, 34, 897-908. doi:10.1111/j.1600-0587.2011.06919.x.

Archie, E. A., Luikart, G., \& Ezenwa, V. O. (2008). Infecting epidemiology with genetics: a new frontier in disease ecology. Trends in Ecology \& Evolution, 24, 21-30. doi:10.1016/j. tree.2008.08.008.

Ayres, M. P., \& Lombardero, M. J. (2000). Assessing the consequences of global change for forest disturbance from 
herbivores and pathogens. Science of the Total Environment, 262, 263-286. doi:10.1016/S0048-9697(00)00528-3.

Baeten, L., De Frenne, P., Verheyen, K., Graae, B. J., \& Henry, M. (2010). Forest herbs in the face of global change: a single-species-multiple-threats approach for Anemone nemorosa. Plant Ecology \& Evolution, 143, 19-30. doi: $10.5091 /$ plecevo.2010.414.

Baker, R. H. A., Sansford, C. E., Jarvis, C. H., Cannon, R. J. C., MacLeod, A., \& Walters, K. F. A. (2000). The role of climatic mapping in predicting the potential geographical distribution of non-indigenous pests under current and future climates. Agriculture, Ecosystems \& Environment, 82, 57-71. doi:10.1016/S0167-8809(00)00216-4.

Barnes, A. P., Wreford, A., Butterworth, M. H., Semenov, M. A., Moran, D., Evans, N., et al. (2010). Adaptation to increasing severity of phoma stem canker on winter oilseed rape in the UK under climate change. Journal of Agricultural Science, 148, 683-694. doi:10.1017/S002185961000064X.

Barrès, B., Halkett, F., Dutech, C., Andrieux, A., Pinon, J., \& Frey, P. (2008). Genetic structure of the poplar rust fungus Melampsora larici-populina: evidence for isolation by distance in Europe and recent founder effects overseas. Infection, Genetics and Evolution, 8, 577-587. doi:10.1016/j. meegid.2008.04.005.

Baumgartner, K., Travadon, R., Bruhn, J., \& Bergemann, S. E. (2010). Contrasting patterns of genetic diversity and population structure of Armillaria mellea sensu stricto in the eastern and western United States. Phytopathology, 100, 708-718. doi:10.1094/PHYTO-100-7-0708.

Bawa, K. S., \& Dayanandan, S. (1998). Global climatic change and tropical forest genetic resources. Climatic Change, 39, 473-485. doi:10.1023/A:1005360223639.

Bearchell, S. J., Fraaije, B. A., Shaw, M. W., \& Fitt, B. D. L. (2005). Wheat archive links long-term fungal pathogen population dynamics to air pollution. Proceedings of the National Academy of Sciences USA, 102, 5438-5442. doi:10.1073/pnas.0501596102.

Beaumont, L. J., Pitman, A., Perkins, S., Zimmermann, N. E., Yoccoz, N. G., \& Thuiller, W. (2011). Impacts of climate change on the world's most exceptional ecoregions. Proceedings of the National Academy of Sciences USA, 108, 2306-2311. doi:10.1073/pnas.1007217108.

Bengtsson, S. B. K., Vasaitis, R., Kirisits, T., Solheim, H., \& Stenlid, J. (2012). Population structure of Hymenoscyphus pseudoalbidus and its genetic relationship to Hymenoscyphus albidus. Fungal Ecology, in press doi:10.1016/j. funeco.2011.10.004

Bentz, B. J., Régnière, J., Fettig, C. J., Hansen, E. M., Hayes, J. L., Hicke, J. A., et al. (2010). Climate change and bark beetles of the Western United States and Canada: direct and indirect effects. BioScience, 60, 602-613. doi:10.1525/ bio.2010.60.8.6.

Benvenuti, S. (2009). Potenziale impatto dei cambiamenti climatici nell'evoluzione floristica di fitocenosi spontanee in agroecosistemi mediterranei. Rivista Italiana di Agronomia, S1, 45-67.

Bergot, M., Cloppet, E., Pérarnaud, V., Déqué, M., Marçais, B., \& Desprez-Loustau, M.-L. (2004). Simulation of potential range expansion of oak disease caused by Phytophthora cinnamomi under climate change. Global Change Biology, 10, 1539-1552. doi:10.1111/j.1365-2486.2004.00824.x.
Bernier, P. Y., Desjardins, R. L., Karimi-Zindashty, Y., Worth, D., Beaudoin, A., Luo, Y., et al. (2011). Boreal lichen woodlands: a possible negative feedback to climate change in eastern North America. Agricultural and Forest Meteorology, 151, 521-528. doi:10.1016/j.agrformet.2010.12.013.

Blankinship, J. C., Niklaus, P. A., \& Hungate, B. A. (2011). A meta-analysis of responses of soil biota to global change. Oecologia, 165, 553-565. doi:10.1007/s00442-011-1909-0.

Bock, C. H., Poole, G. H., Parker, P. E., \& Gottwald, T. R. (2010). Plant disease severity estimated visually, by digital photography and image analysis, and by hyperspectral imaging. Critical Reviews in Plant Sciences, 29, 59-107. doi:10.1080/07352681003617285.

Bodin, P., \& Wiman, B. L. B. (2007). The usefulness of stability concepts in forest management when coping with increasing climate uncertainties. Forest Ecology and Management, 242, 541-552. doi:10.1016/j.foreco.2007.01.066.

Boland, G. J., Melzer, M. S., Hopkin, A., Higgins, V., \& Nassuth, A. (2004). Climate change and plant diseases in Ontario. Canadian Journal of Plant Pathology, 26, 335350. doi:10.1080/07060660409507151.

Bradford, J. B., \& D'Amato, A. W. (2012). Recognizing trade-offs in multi-objective land management. Frontiers in Ecology and the Environment, in press doi:10.1890/110031

Bradley, B. A., Blumenthal, D. M., Early, R., Grosholz, E. D., Lawler, J. J., Miller, L. P., et al. (2012). Global change, global trade, and the next wave of plant invasions. Frontiers in Ecology and the Environment, in press doi:10.1890/110145

Brasier, C., \& Webber, J. (2010). Sudden larch death. Nature, 466, 824-825. doi:10.1038/466824a.

Britton, K. O., White, P., Kramer, A., \& Hudler, G. (2010). A new approach to stopping the spread of invasive insects and pathogens: early detection and rapid response via a global network of sentinel plantings. New Zealand Journal of Forestry Science, 40, 109-114.

Brosi, G. B., McCulley, R. L., Bush, L. P., Nelson, J. A., Classen, A. T., \& Norby, R. J. (2010). Effects of multiple climate change factors on the tall fescue-fungal endophyte symbiosis: infection frequency and tissue chemistry. New Phytologist, 189, 797-805. doi:10.1111/j.1469-8137.2010.03532.x.

Brown, J. K. M., \& Hovmøller, M. S. (2002). Aerial dispersal of pathogens on the global and continental scales and its impact on plant disease. Science, 297, 537-541. doi:10.1126/science.1072678.

Brummer, E. C., Barber, W. T., Collier, S. M., Cox, T. S., Johnson, R., Murray, S. C., et al. (2011). Plant breeding for harmony between agriculture and the environment. Frontiers in Ecology and the Environment, 9, 561-568. doi:10.1890/100225.

Burdon, J. J., \& Thrall, P. H. (2008). Pathogen evolution across the agro-ecological interface: implications for disease management. Evolutionary Applications, 1, 57-65. doi:10.1111/j.1752-4571.2007.00005.x.

Burdon, J. J., Thrall, P. H., \& Ericson, L. (2006). The current and future dynamics of disease in plant communities. Annual Review of Phytopathology, 44, 19-39. doi:10.1146/ annurev.phyto.43.040204.140238.

Busby, P. E., \& Canham, C. D. (2011). An exotic insect and pathogen disease complex reduces aboveground tree biomass in temperate forests of eastern North America. Canadian Journal of Forest Research, 41, 401-411. doi:10.1139/X10213. 
Butterworth, M. H., Semenov, M. A., Barnes, A., Moran, D., West, J. S., \& Fitt, B. D. L. (2010). North-South divide: contrasting impacts of climate change on crop yields in Scotland and England. Journal of the Royal Society, Interface, 7, 123-130. doi:10.1098/rsif.2009.0111.

Calder, J. A., \& Kirkpatrick, J. B. (2008). Climate change and other factors influencing the decline of the Tasmanian cider gum (Eucalyptus gunnii). Australian Journal of Botany, 56, 684-692. doi:10.1071/BT08105.

Carnicer, J., Coll, M., Ninyerola, M., Pons, X., Sánchez, G., \& Peñuelas, J. (2011). Widespread crown condition decline, food web disruption, and amplified tree mortality with increased climate change-type drought. Proceedings of the National Academy of Sciences USA, 108, 1474-1478. doi:10.1073/pnas.1010070108.

Cerri, C. E. P., Sparovek, G., Bernoux, M., Easterling, W. E., Melillo, J. M., \& Cerri, C. C. (2007). Tropical agriculture and global warming: impacts and mitigation options. Scientia Agricola, 64, 83-99.

Chadès, I., Martin, T. G., Nicol, S., Burgman, M. A., Possingham, H. P., \& Buckley, Y. M. (2011). General rules for managing and surveying networks of pests, diseases, and endangered species. Proceedings of the National Academy of Sciences USA, 108, 8323-8328. doi:10.1073/pnas.1016846108.

Chakraborty, S. (2005). Potential impact of climate change on plant-pathogen interactions. Australasian Plant Pathology, 34, 443-448. doi:10.1071/AP05084.

Chakraborty, S., \& Datta, S. (2003). How will plant pathogens adapt to host plant resistance at elevated $\mathrm{CO}_{2}$ under a changing climate? New Phytologist, 159, 733-742. doi:10.1046/j.1469-8137.2003.00842.x.

Chakraborty, S., \& Newton, A. C. (2011). Climate change, plant diseases and food security: an overview. Plant Pathology, 60, 2-14. doi:10.1111/j.1365-3059.2010.02411.x.

Chakraborty, S., Tiedemann, A. V., \& Teng, P. S. (2000). Climate change: potential impact on plant diseases. Environmental Pollution, 108, 317-326. doi:10.1016/S0269-7491 (99)00210-9.

Chakraborty, S., Luck, J., Hollaway, G., Freeman, A., Norton, R., Garrett, K. A., et al. (2008). Impacts of global change on diseases of agricultural crops and forest trees. $C A B$ Reviews, 3, 054. doi:10.1079/PAVSNNR20083054.

Chakraborty, S., Luck, J., Hollaway, G., Fitzgerald, G., \& White, N. (2011). Rust-proofing wheat for a changing climate. Euphytica, 179, 19-32. doi:10.1007/s10681-010-0324-7.

Chimera, C. G., Buddenhagen, C. E., \& Clifford, P. M. (2010). Biofuels: the risks and dangers of introducing invasive species. Biofuels, 1, 785-796. doi:10.4155/bfs.10.47.

Chytrý, M., Wild, J., Pyšek, P., Jarošík, V., Dendoncker, N., Reginster, I., et al. (2012). Projecting trends in plant invasions in Europe under different scenarios of future land-use change. Global Ecology and Biogeography, 21, 75-87. doi:10.1111/j.1466-8238.2010.00573.x.

Ciscar, J.-C., Iglesias, A., Feyen, L., Szabó, L., Van Regemorter, D., Amelung, B., et al. (2011). Physical and economic consequences of climate change in Europe. Proceedings of the National Academy of Sciences USA, 108, 26782683. doi:10.1073/pnas.1011612108.

Clough, Y., Barkmann, J., Juhrbandt, J., Kessler, M., Wanger, T. C., Anshary, A., et al. (2011). Combining high biodiversity with high yields in tropical agroforests. Proceedings of the
National Academy of Sciences USA, 108, 8311-8316. doi:10.1073/pnas.1016799108.

Coakley, S. M. (1995). Biospheric change - will it matter in plant pathology. Canadian Journal of Plant Pathology, 17, 147-153.

Coakley, S. M., Scherm, H., \& Chakraborty, S. (1999). Climate change and plant disease management. Annual Review of Phytopathology, 37, 399-426. doi:10.1146/annurev. phyto.37.1.399.

Cobb, R. C., Chan, M. N., Meentemeyer, R. K., \& Rizzo, D. M. (2012). Common factors drive disease and coarse woody debris dynamics in forests impacted by Sudden Oak Death. Ecosystems, in press doi:10.1007/s10021-011-9506-y

Compant, S., van der Heijden, M. G. A., \& Sessitsch, A. (2010). Climate change effects in beneficial plant-microorganism interactions. FEMS Microbiology Ecology, 73, 197-214. doi:10.1111/j.1574-6941.2010.00900.x.

Crall, A. W., Newman, G. J., Jarnevich, C. S., Stohlgren, T. J., Waller, D. M., \& Graham, J. (2010). Improving and integrating data on invasive species collected by citizen scientists. Biological Invasions, 12, 3914-3928. doi:10.1007/ s10530-010-9740-9.

Crowder, D. W., Northfield, T. D., Strand, M. R., \& Snyder, W. E. (2010). Organic agriculture promotes evenness and natural pest control. Nature, 466, 109-112. doi:10.1038/ nature09183.

Dale, V., Archer, S., Chang, M., \& Ojima, D. (2005). Ecological impacts and mitigation strategies for rural land management. Ecological Applications, 15, 1879-1892. doi:10.1890/03-5330.

Dale, A. L., Lewis, K. J., \& Murray, B. W. (2011). Sexual reproduction and gene flow in the pine pathogen Dothistroma septosporum in British Columbia. Phytopathology, 101, 68-76. doi:10.1094/PHYTO-04-10-0121.

Danon, L., Ford, A. P., House, T., Jewell, C. P., Keeling, M. J., Roberts, G. O., et al. (2011). Networks and the epidemiology of infectious disease. Interdisciplinary Perspectives on Infectious Diseases, 2011, 284909. doi:10.1155/2011/284909.

Davies, L., Bell, J. N. B., Bone, J., Head, M., Hill, L., Howard, C., et al. (2011). Open Air Laboratories (OPAL): a communitydriven research programme. Environmental Pollution, 159, 2203-2210. doi:10.1016/j.envpol.2011.02.053.

De Simone, D., D’Amico, L., Bressanin, D., Motta, E., \& Annesi, T. (2011). Molecular characterization of Inonotus rickii/Ptychogaster cubensis isolates from different geographic provenances. Mycological Progress, 10, 301-306. doi:10.1007/s11557-010-0702-5.

Dehnen-Schmutz, K., Holdenrieder, O., Jeger, M. J., \& Pautasso, M. (2010). Structural change in the international horticultural industry: some implications for plant health. Scientia Horticulturae, 125, 1-15. doi:10.1016/j.scienta.2010.02.017.

Deslippe, J. R., Hartmann, M., Mohn, W. W., \& Simard, S. W. (2010). Long-term experimental manipulation of climate alters the ectomycorrhizal community of Betula nana in Arctic tundra. Global Change Biology, 17, 1625-1636. doi:10.1111/j.1365-2486.2010.02318.x.

Desprez-Loustau, M. L., Marçais, B., Nageleisen, L.-M., Piou, D., \& Vannini, A. (2006). Interactive effects of drought and pathogens in forest trees. Annals of Forest Science, 63, 597-612. doi:10.1051/forest:2006040.

Desprez-Loustau, M. L., Robin, C., Buee, M., Courtecuisse, R., Garbaye, R., Suffert, F., et al. (2007a). The fungal 
dimension of biological invasions. Trends in Ecology \& Evolution, 22, 472-480. doi:10.1016/j.tree.2007.04.005.

Desprez-Loustau, M. L., Robin, C., Reynaud, G., Deque, M., Badeau, V., Piou, D., et al. (2007b). Simulating the effects of a climate-change scenario on the geographical range and activity of forest-pathogenic fungi. Canadian Journal of Plant Pathology, 29, 101-120.

Dillon, M. E., Wang, G., \& Huey, R. B. (2010). Global metabolic impacts of recent climate warming. Nature, 467, 704-707. doi:10.1038/nature09407.

Dobson, A. (2009). Climate variability, global change, immunity, and the dynamics of infectious diseases. Ecology, 90, 920-927. doi:10.1890/08-0736.1.

Dodd, R. S., Hüberli, D., Mayer, W., Harnik, T. Y., Afzal-Rafii, Z., \& Garbelotto, M. (2008). Evidence for the role of synchronicity between host phenology and pathogen activity in the distribution of sudden oak death canker disease. New Phytologist, 179, 505-514. doi:10.1111/j.1469-8137.2008.02450.x.

Donnelly, A., Caffarra, A., \& O’Neill, B. F. (2011). A review of climate-driven mismatches between interdependent phenophases in terrestrial and aquatic ecosystems. International Journal of Biometeorology, 55, 805-817. doi:10.1007/ s00484-011-0426-5.

Döring, T. F., Knapp, S., Kovacs, G., Murphy, K., \& Wolfe, M. S. (2011). Evolutionary plant breeding in cereals - into a new era. Sustainability, 3, 1944-1971. doi:10.3390/su3101944.

Dutech, C., Fabreguettes, O., Capdevielle, X., \& Robin, C. (2010). Multiple introductions of divergent genetic lineages in an invasive fungal pathogen, Cryphonectria parasitica, in France. Heredity, 105, 220-228. doi:10.1038/hdy.2009.164.

Eastburn, D. M., Degennaro, M. M., Delucial, E. H., Demody, O., \& McElrone, A. J. (2009). Elevated atmospheric carbon dioxide and ozone alter soybean diseases at SoyFACE. Global Change Biology, 16, 320-330. doi:10.1111/j.13652486.2009.01978.x.

Eastburn, D. M., McElrone, A. J., \& Bilgin, D. D. (2011). Influence of atmospheric and climatic change on plantpathogen interactions. Plant Pathology, 60, 54-69. doi:10.1111/j.1365-3059.2010.02402.x.

Egli, S. (2011). Mycorrhizal mushroom diversity and productivity - an indicator of forest health? Annals of Forest Science, 68, 81-88. doi:10.1007/s13595-010-0009-3.

Engler, R., Randin, C. F., Thuiller, W., Dullinger, S., Zimmermann, N. E., Araujo, M. B., et al. (2011). 21st century climate change threatens mountain flora unequally across Europe. Global Change Biology, 17, 2330-2341. doi:10.1111/j.13652486.2010.02393.x.

Erlacher, E., \& Wang, M. (2011). Regulation (EC) No. 1107/ 2009 and upcoming challenges for exposure assessment of plant protection products - harmonisation or national modelling approaches? Environmental Pollution, 159, 33573363. doi:10.1016/j.envpol.2011.08.036.

Ewers, R. M., Scharlemann, J. P. W., Balmford, A. P., \& Green, R. E. (2009). Do increases in agricultural yield spare land for nature? Global Change Biology, 15, 1716-1726. doi:10.1111/j.1365-2486.2009.01849x.

Fabre, B., Piou, D., Desprez-Loustau, M.-L., \& Marçais, B. (2011). Can the emergence of pine Diplodia shoot blight in France be explained by changes in pathogen pressure linked to climate change? Global Change Biology, 17, 3218-3227. doi:10.1111/j.1365-2486.2011.02428.x.
Finckh, M. R., \& Wolfe, M. S. (1996). The use of biodiversity to restrict plant diseases and some consequences for farmers and society. In L. E. Jackson (Ed.), Ecology in agriculture (pp. 203-237). Dordrecht: Elsevier. doi:10.1016/B978012378260-1/50008-7.

Fischer, J., Zerger, A., Gibbons, P., Stott, J., \& Law, B. S. (2010). Tree decline and the future of Australian farmland biodiversity. Proceedings of the National Academy of Sciences USA, 107, 19597-19602. doi:10.1073/pnas.1008476107.

Fischer, A. R. H., Tobi, H., \& Ronteltap, A. (2011). When natural met social: a review of collaboration between the natural and social sciences. Interdisciplinary Science Reviews, 36, 341358. doi:10.1179/030801811X13160755918688.

Fitt, G. P. (2011). Critical issues in pest management for a future with sustainable biofuel cropping. Current Opinion in Environmental Sustainability, 3, 71-74. doi:10.1016/j. cosust.2010.11.008.

Fitt, B. D. L., Fraaije, B. A., Chandramohan, P., \& Shaw, M. W. (2011). Impacts of changing air composition on severity of arable crop disease epidemics. Plant Pathology, 60, 44-53. doi:10.1111/j.1365-3059.2010.02413.x.

Fitter, A. (2012). Why plant science matters. New Phytologist, 193, 1-2. doi:10.1111/j.1469-8137.2011.03995.x.

Fleischmann, F., Raidl, S., \& Osswald, W. F. (2010). Changes in susceptibility of beech (Fagus sylvatica) seedlings towards Phytophthora citricola under the influence of elevated atmospheric $\mathrm{CO}_{2}$ and nitrogen fertilization. Environmental Pollution, 158, 1051-1060. doi:10.1016/j.envpol.2009.10.004.

Fletcher, J., Franz, D., \& LeClerc, E. J. (2009). Healthy plants: necessary for a balanced 'One Health' concept. Veterinaria Italiana, 45, 79-95. http://www.izs.it/vet_italiana/2009/ 45 1/79.pdf

Flood, J. (2010). The importance of plant health to food security. Food Security, 2, 215-231. doi:10.1007/s12571-010-0072-5.

French, S., Levy-Booth, D., Samarajeewa, A., Shannon, K. E., Smith, J., \& Trevors, J. T. (2009). Elevated temperatures and carbon dioxide concentrations: effects on selected microbial activities in temperate agricultural soils. World Journal of Microbiology and Biotechnology, 25, 18871900. doi:10.1007/s11274-009-0107-2.

Fuhrer, J. (2003). Agroecosystem responses to combinations of elevated $\mathrm{CO}_{2}$, ozone, and global climate change. Agriculture, Ecosystems \& Environment, 97, 1-20. doi:10.1016/ S0167-8809(03)00125-7.

Fuhrer, J., Beniston, M., Fischlin, A., Frei, Ch, Goyette, S., Jasper, K., et al. (2006). Climate risks and their impact on agriculture and forests in Switzerland. Climatic Change, 79, 79-102. doi:10.1007/s10584-006-9106-6.

Furstenau, C., Badeck, F. W., Lasch, P., Lexer, M. J., Lindner, M., Mohr, P., et al. (2007). Multiple-use forest management in consideration of climate change and the interests of stakeholder groups. European Journal of Forest Research, 126, 225-239. doi:10.1007/s10342-006-0114-x.

Gange, A. C., Gange, E. G., Mohammad, A. B., \& Boddy, L. (2011). Host shifts in fungi caused by climate change? Fungal Ecology, 4, 184-190. doi:10.1016/j.funeco.2010.09.004.

Ganley, R. J., Watt, M. S., Kriticos, D. J., Hopkins, A. J. M., \& Manning, L. K. (2011). Increased risk of pitch canker to Australasia under climate change. Australasian Plant Pathology, 40, 228-237. doi:10.1007/s13313-0110033-2. 
Garbelotto, M. (2008). Molecular analysis to study invasions by forest pathogens: examples from Mediterranean ecosystems. Phytopathologia Mediterranea, 47, 183-203.

Garbelotto, M., \& Pautasso, M. (2012). Impacts of exotic forest pathogens on Mediterranean ecosystems: four case studies European Journal of Plant Pathology, in press doi:10.1007/s10658-011-9928-6

Garbelotto, M., Linzer, L., Nicolotti, G., \& Gonthier, P. (2010). Comparing the influences of ecological and evolutionary factors on the successful invasion of a fungal forest pathogen. Biological Invasions, 12, 943-957. doi:10.1007/ s10530-009-9514-4.

Garrett, K. A. (2008). Climate change and plant disease risk. In D. A. Relman, M. A. Hamburg, E. R. Choffnes, \& A. Mack (Eds.), Global climate change and extreme weather events: understanding the contributions to infectious disease emergence (pp. 143-155). Washington, DC: National Academies Press.

Garrett, K. A., \& Mundt, C. C. (1999). Epidemiology in mixed host populations. Phytopathology, 89, 984-990. doi:10.1094/PHYTO.1999.89.11.984.

Garrett, K. A., Dendy, S. P., Frank, E. E., Rouse, M. N., \& Travers, S. E. (2006). Climate change effects on plant disease: genomes to ecosystems. Annual Review of Phytopathology, 44, 489-509. doi:10.1146/annurev.phyto.44.070505.143420.

Garrett, K. A., Nita, M., De Wolf, E. D., Gomez, L., \& Sparks, A. H. (2009). Plant pathogens as indicators of climate change. In T. Letcher (Ed.), Climate change: observed impacts on planet Earth (pp. 425-437). Dordrecht: Elsevier.

Garrett, K. A., Forbes, G. A., Savary, S., Skelsey, P., Sparks, A. H., Valdivia, C., et al. (2011). Complexity in climatechange impacts: an analytical framework for effects mediated by plant disease. Plant Pathology, 60, 15-30. doi:10.1111/j.1365-3059.2010.02409.x.

Geyer, J., Kiefer, I., Kreft, S., Chavez, V., Salafsky, N., Jeltsch, F., et al. (2011). Classification of climate-change-induced stresses on biological diversity. Conservation Biology, 25, 708-715. doi:10.1111/j.1523-1739.2011.01676.x.

Ghini, R., Hamada, E., \& Bettiol, W. (2008). Climate change and plant diseases. Scientia Agricola, 65, 98-107. doi:10.1590/S0103-90162008000700015.

Ghini, R., Bettiol, W., \& Hamada, E. (2011a). Diseases in tropical and plantation crops as affected by climate changes: current knowledge and perspectives. Plant Pathology, 60, 122-132. doi:10.1111/j.1365-3059.2010.02403.x.

Ghini, R., Hamada, E., Pedro Junior, M. J., \& Goncalves, R. Rd. V. (2011b). Incubation period of Hemileia vastatrix in coffee plants in Brazil simulated under climate change. Summa Phytopathologica, 37, 85-93. doi:10.1590/S010054052011000200001.

Golding, J., Güsewell, S., Kreft, H., Kuzevanov, V. Y., Lehvävirta, S., Parmentier, I., et al. (2010). Species-richness patterns of the living collections of the world's botanic gardens: a matter of socio-economics? Annals of Botany, 105, 689-696. doi:10.1093/aob/mcq043.

Gregory, P. J., Johnson, S. N., Newton, A. C., \& Ingram, J. S. I. (2009). Integrating pests and pathogens into the climate change/food security debate. Journal of Experimental Botany, 60, 2827-2838. doi:10.1093/jxb/erp080.

Gross, A., Grünig, C. R., Queloz, V., \& Holdenrieder, O. (2012). A molecular toolkit for population genetic investigations of the ash dieback pathogen Hymenoscyphus pseudoalbidus. Forest Pathology, in press doi:10.1111/j.1439-0329.2011.00751.x

Grulke, N. E. (2011). The nexus of host and pathogen phenology: understanding the disease triangle with climate change. New Phytologist, 189, 8-11. doi:10.1111/j.14698137.2010.03568.x.

Gurr, S., Samalova, M., \& Fisher, M. (2011). The rise and rise of emerging infectious fungi challenges food security and ecosystem health. Fungal Biology Reviews, 25, 181-188. doi:10.1016/j.fbr.2011.10.004.

Hakala, K., Hannukkala, A. O., Huusela-Veistola, E., Jalli, M., \& Peltonen-Sainio, P. (2011). Pests and diseases in a changing climate: a major challenge for Finnish crop production. Agricultural and Food Science, 20, 3-14. doi:10.2137/145960611795163042.

Hannukkala, A. O. (2011). Examples of alien pathogens in Finnish potato production - their introduction, establishment and consequences. Agricultural and Food Science, 20, 42-61. doi:10.2137/145960611795163024.

Hannukkala, A. O., Kaukoranta, T., Lehtinen, A., \& Rahkonen, A. (2007). Late-blight epidemics on potato in Finland, 19332002; increased and earlier occurrence of epidemics associated with climate change and lack of rotation. Plant Pathology, 56, 167-176. doi:10.1111/j.1365-3059.2006.01451.x.

Haq, M., Taher Mia, M. A., Rabbi, M. F., \& Ali, M. A. (2011). Incidence and severity of rice diseases and insect pests in relation to climate change. In R. Lal, M. V. K. Sivakumar, S. M. A. Faiz, A. H. M. M. Rahman, \& K. R. Islam (Eds.), Climate change and food security in South Asia (pp. 445457). Berlin: Springer. doi:10.1007/978-90-481-9516-9 27.

Harwood, T. D., Xu, X. M., Pautasso, M., Jeger, M. J., \& Shaw, M. (2009). Epidemiological risk assessment using linked network and grid based modelling: Phytophthora ramorum and P. kernoviae in the UK. Ecological Modelling, 220, 3353-3361.

Hawkes, C. V., Kivlin, S. N., Rocca, J. D., Huguet, V., Thomsen, M. A., \& Suttle, K. B. (2011). Fungal community responses to precipitation. Global Change Biology, 17, 1637-1645. doi:10.1111/j.1365-2486.2010.02327.x.

Hegerl, G. C., Hanlon, H., \& Beierkuhnlein, C. (2011). Climate science: elusive extremes. Nature Geoscience, 4, 142-143. doi::10.1038/ngeo1090.

Heyder, U., Schaphoff, S., Gerten, D., \& Lucht, W. (2011). Risk of severe climate change impact on the terrestrial biosphere. Environmental Research Letters, 6, 034036. doi::10.1088/1748-9326/6/3/034036.

Holdenrieder, O., Pautasso, M., Weisberg, P. J., \& Lonsdale, D. (2004). Tree diseases and landscape processes: the challenge of landscape pathology. Trends in Ecology \& Evolution, 19, 446-452. doi:10.1016/j.tree.2004.06.003.

Holdenrieder, O., Pautasso, M., \& Weisberg, P. J. (2008). Tree disease management in heterogeneous landscapes. Oral presentation at the 9th International Conference of Plant Pathology (ICPP 9-Health and Safe Food for Everybody), Torino, Italy, 24-29 August 2008.

Horan, R. D., \& Lupi, F. (2010). The economics of invasive species control and management: the complex road ahead. Resource and Energy Economics, 32, 477-482. doi:10.1016/j.reseneeco.2010.07.001.

Ingram, J. S. I., Gregory, P. J., \& Izac, A.-M. (2008). The role of agronomic research in climate change and food security 
policy. Agriculture, Ecosystems and Environment, 126, 412. doi:10.1016/j.agee.2008.01.009.

Ingwell, L. L., \& Preisser, E. L. (2011). Using citizen science programs to identify host resistance in pest-invaded forests. Conservation Biology, 25, 182-188. doi:10.1111/j.15231739.2010.01567.x.

Jacobi, W. R., Crump, A., \& Lundquist, J. E. (2011). Dissemination of forest health research information in the Rocky Mountains. Journal of Forestry, 109, 43-49.

Jarvis, D. I., Hodgkin, T., Sthapit, B. R., Fadda, C., \& LopezNoriega, I. (2011). An heuristic framework for identifying multiple ways of supporting the conservation and use of traditional crop varieties within the agricultural production system. Critical Reviews in Plant Science, 30, 125-176. doi:10.1080/07352689.2011.554358.

Jeger, M. J., \& Pautasso, M. (2008). Plant disease and global change - the importance of long-term data sets. New Phytologist, 177, 8-11. doi:10.1111/j.1469-8137.2007.02312.x.

Jeger, M. J., Pautasso, M., Holdenrieder, O., \& Shaw, M. W. (2007). Modelling disease spread and control in networks: implications for plant sciences. New Phytologist, 174, 279 297. doi:10.1111/j.1469-8137.2007.02028.x.

Jeger, M., Pautasso, M., \& Stack, J. (2011). Climate, globalization and trade: impacts on dispersal and invasion of fungal plant pathogens. In L. A. Olsen, D. A. Relman, E. R. Choffnes, \& L. Pray (Eds.), Fungal diseases: an emerging challenge to human, animal and plant health (pp. 273296). Washington, DC: Institute of Medicine of the National Academies.

Jombart, T., Eggo, R. M., Dodd, P. J., \& Balloux, F. (2011). Reconstructing disease outbreaks from genetic data: a graph approach. Heredity, 106, 383-390. doi:10.1038/hdy.2010.78.

Jones, R. A. C. (2009). Plant virus emergence and evolution: origins, new encounter scenarios, factors driving emergence, effects of changing world conditions, and prospects for control. Virus Research, 141, 113-130. doi:10.1016/j. virusres.2008.07.028.

Jung, T., Stukely, M. J. C., Hardy, G. E. S. J., White, D., Paap, T., Dunstan, W. A., et al. (2011). Multiple new Phytophthora species from ITS Clade 6 associated with natural ecosystems in Australia: evolutionary and ecological implications. Persoonia, 26, 13-39. doi:10.3767/003158511X557577.

Juroszek, P., \& von Tiedemann, A. (2011). Potential strategies and future requirements for plant disease management under a changing climate. Plant Pathology, 60, 100-112. doi:10.1111/j.1365-3059.2010.02410.x.

Keesing, F., Belden, L. K., Daszak, P., Dobson, A., Harvell, C. D., Holt, R. D., et al. (2010). Impacts of biodiversity on the emergence and transmission of infectious diseases. Nature, 468, 647-652. doi:10.1038/nature09575.

Keller, R. P., Drake, J. M., Drew, M. B., \& Lodge, D. M. (2011). Linking environmental conditions and ship movements to estimate invasive species transport across the global shipping network. Diversity and Distributions, 17, 93-102. doi:10.1111/j.1472-4642.2010.00696.x.

King, J. N., David, A., Noshad, D., \& Smith, J. (2010). A review of genetic approaches to the management of blister rust in white pines. Forest Pathology, 40, 292-313. doi:10.1111/j.1439-0329.2010.00659.x.

Kjær, E. D., McKinney, L. V., Nielsen, L. R., Hansen, L. N. \& Hansen, J. K. (2012). Adaptive potential of ash (Fraxinus excelsior) populations against the novel emerging pathogen Hymenoscyphus pseudoalbidus. Evolutionary Applications, in press doi:10.1111/j.1752-4571.2011.00222.x

Kliejunas, J. T., Geils, B. W., Glaeser, M. J., Goheen, E. M., Hennon, P., Kim, M.-S., et al. (2008). Climate and forest diseases of Western North America: a literature review. PSW-GTR, USDA FS, p. 44

Klopfenstein, N. B., Kim, M.-S., Hanna, J. W., Richardson, B. A., \& Lundquist, J. (2009). Approaches to predicting potential impacts of climate change on forest disease: an example with Armillaria root disease. USDA Forest Service, Rocky Mountain Research Station, RMRS-RP-76, pp. 16 http://www.fs.fed.us/rm/pubs/rmrs_rp076.pdf

Körner, C. (2003). Ecological impacts of atmospheric $\mathrm{CO}_{2}$ enrichment on terrestrial ecosystems. Philosophical Transactions of the Royal Society London A, 361, 2023-2041. doi:10.1098/rsta.2003.1241.

Körner, C., \& Basler, D. (2010). Phenology under global warming. Science, 327, 1461-1462. doi:10.1126/science.1186473.

Kozlov, M. V., \& Zvereva, E. L. (2011). A second life for old data: global patterns in pollution ecology revealed from published observational studies. Environmental Pollution, 159, 1067-1075. doi:10.1016/j.envpol.2010.10.028.

Kraj, W., Zarek, M., \& Kowalski, T. (2012). Genetic variability of Chalara fraxinea, dieback cause of European ash (Fraxinus excelsior L.). Mycological Progress, in press doi:10.1007/ s11557-010-0724-Z

Kůdela, V. (2009). Potential impact of climate change on geographic distribution of plant pathogenic bacteria in Central Europe. Plant Protection Science, 45, S27-S32.

Kulakowski, D., Bebi, P., \& Rixen, C. (2011). The interacting effects of land use change, climate change and suppression of natural disturbances on landscape forest structure in the Swiss alps. Oikos, 120, 216-225. doi:10.1111/j.16000706.2010.18726.x.

La Porta, N., Capretti, P., Thomsen, I. M., Kasanen, R., Hietala, A. M., \& Von Weissenberg, K. (2008). Forest pathogens with higher damage potential due to climate change in Europe. Canadian Journal of Plant Pathology, 30, 177-195.

Lambin, E. F., \& Meyfroidt, P. (2011). Global land use change, economic globalization, and the looming land scarcity. Proceedings of the National Academy of Sciences USA, 108, 3465-3472. doi:10.1073/pnas.1100480108.

Lin, B. B. (2011). Resilience in agriculture through crop diversification: adaptive management for environmental change. BioScience, 61, 183-193. doi:10.1525/bio.2011.61.3.4.

Logan, J. A., Régnière, J., \& Powell, J. A. (2003). Assessing the impacts of global warming on forest pest dynamics. Frontiers in Ecology and the Environment, 1, 130-137. doi:10.1890/1540-9295(2003) 001[0130:ATIOGW]2.0. $\mathrm{CO} ; 2$.

Lonsdale, D., \& Gibbs, J. N. (1995). Effects of climate change on fungal diseases of trees. In J. E. Frankland, N. Magan, \& G. M. Gadd (Eds.), Fungi and environmental change (pp. 1-19). Cambridge: Cambridge University Press.

Lonsdale, D., \& Gibbs, J. (2002). Effects of climate change on fungal diseases of trees. (In M. Broadmeadow (Ed.) Climate change: impacts on UK forests (pp. 83-97). Forestry Commission Bulletin, Nr. 125.)

Lonsdale, D., Pautasso, M., \& Holdenrieder, O. (2008). Wooddecaying fungi in the forest: conservation needs and 
management options. European Journal of Forest Research, 127, 1-22. doi:10.1007/s10342-007-0182-6.

Loustau, D., Ogee, J., Dufrene, E., Deque, M., Dupouey, J. L., Badeau, V., et al. (2007). Impacts of climate change on temperate forests and interaction with management. In P. H. FreerSmith, M. S. J. Broadmeadow, \& J. M. Lynch (Eds.), Forestry and climate change (pp. 243-250). Wallingford, UK: CABI.

Lovett, G. M., Arthur, M. A., Weathers, K. C., \& Griffin, J. M. (2010). Long-term changes in forest carbon and nitrogen cycling caused by an introduced pest/pathogen complex. Ecosystems, 13, 1188-1200. doi:10.1007/s10021-010-9381-y.

Luck, J., Spackman, M., Freeman, A., Trebicki, P., Griffiths, W., Finlay, K., et al. (2011). Climate change and diseases of food crops. Plant Pathology, 60, 113-121. doi:10.1111/ j.1365-3059.2010.02414.x.

MacLeod, A., Pautasso, M., Jeger, M. J., \& Haines-Young, R. (2010). Evolution of the international regulation of plant pests, plant health and challenges for the future. Food Security, 2, 49-70. doi:10.1007/s12571-010-0054-7.

Madgwick, J. W., West, J. S., White, R. P., Semenov, M. A., Townsend, J. A., Turner, J. A., et al. (2011). Impacts of climate change on wheat anthesis and fusarium ear blight in the UK. European Journal of Plant Pathology, 130, 117-131. doi:10.1007/s10658-010-9739-1.

Mahmuti, M., West, J. S., Watts, J., Gladders, P., \& Fitt, B. D. L. (2009). Controlling crop disease contributes to both food security and climate change mitigation. International Journal of Agricultural Sustainability, 7, 189-202. doi:10.3763/ ijas.2009.0476.

Mann, M. E., Bradley, R. S., \& Hughes, M. K. (1998). Globalscale temperature patterns and climate forcing over the past six centuries. Nature, 392, 779-787. doi:10.1038/33859.

Manning, W. J., \& von Tiedemann, A. (1995). Climate change: potential effects of increased atmospheric carbon dioxide $\left(\mathrm{CO}_{2}\right)$, ozone $\left(\mathrm{O}_{3}\right)$, and ultraviolet-B (UV-B) radiation on plant diseases. Environmental Pollution, 88, 219-245. doi:10.1016/0269-7491(95)91446-R.

Marçais, B., \& Desprez-Loustau, M. L. (2007). Le réchauffement climatique a-t-il un impact sur les maladies forestières? RenDez-Vous Techniques, 3, 47-52.

Marçais, B., Bouhot-Delduc, L., \& Le Tacon, F. (2000). Effets possibles des changements globaux sur les microorganismes symbiotiques et pathogènes et les insectes ravageurs des forêts. Revue Forestière Française, 52, 99-118.

Margosian, M. L., Garrett, K. A., Hutchinson, J. M. S., \& With, K. A. (2009). Connectivity of the American agricultural landscape: assessing the national risk of crop pest and disease spread. BioScience, 59, 141-151. doi:10.1525/ bio.2009.59.2.7.

Matesanz, S., Escudero, A., \& Valladares, F. (2009). Impact of three global change drivers on a Mediterranean shrub. Ecology, 90, 2609-2621. doi:10.1890/08-1558.1.

Matesanz, S., Gianoli, E., \& Valladares, F. (2010). Global change and the evolution of phenotypic plasticity in plants. Annals of the New York Academy of Sciences, 1206, 35-55. doi:10.1111/j.1749-6632.2010.05704.x.

Matyssek, R., Wieser, G., Calfapietra, C., de Vries, W., Dizengremel, P., Ernst, D., et al. (2012). Forests under climate change and air pollution: gaps in understanding and future directions for research. Environmental Pollution, 160, 57-65. doi:10.1016/j. envpol.2011.07.007.
McDonald-Madden, E., Runge, M. C., Possingham, H. P., \& Martin, T. G. (2011). Optimal timing for managed relocation of species faced with climate change. Nature Climate Change, 1, 261-265. doi:10.1038/nclimate1170.

McDowell, N. G., Beerling, D. J., Breshears, D. D., Fisher, R. A., Raffa, K. F., \& Stitt, M. (2011). The interdependence of mechanisms underlying climate-driven vegetation mortality. Trends in Ecology \& Evolution, 26, 523-532. doi:10.1016/j.tree.2011.06.003.

McElrone, A. J., Hamilton, J. G., Krafnick, A. J., Aldea, M., Knepp, R. G., \& DeLucia, E. H. (2010). Combined effects of elevated $\mathrm{CO}_{2}$ and natural climatic variation on leaf spot diseases of redbud and sweetgum trees. Environmental Pollution, 158, 108-114. doi:10.1016/j.envpol.2009.07.029.

McKinney, L. V., Nielsen, L. R., Hansen, J. K., \& Kjær, E. D. (2011). Presence of natural genetic resistance in Fraxinus excelsior (Oleraceae) to Chalara fraxinea (Ascomycota): an emerging infectious disease. Heredity, 106, 788-797. doi:10.1038/hdy.2010.119.

Médiène, S., Valantin-Morison, M., Sarthou, J.-P., de Tourdonnet, S., Gosme, M., Bertrand, M., et al. (2011). Agroecosystem management and biotic interactions: a review. Agronomy for Sustainable Development, 31, 491-514. doi:10.1007/ s13593-011-0009-1.

Milad, M., Schaich, H., Bürgi, M., \& Konold, W. (2011). Climate change and nature conservation in Central European forests: a review of consequences, concepts and challenges. Forest Ecology and Management, 261, 829-843. doi:10.1016/j. foreco.2010.10.038.

Millar, C. I., Stephenson, N. L., \& Stephens, S. L. (2007). Climate change and forests of the future: managing in the face of uncertainty. Ecological Applications, 17, 21452151. doi:10.1890/06-1715.1.

Mills, P., Dehnen-Schmutz, K., Ilbery, B., Jeger, M., Jones, G., Little, R., et al. (2011). Integrating natural and social science perspectives on plant disease risk, management and policy formulation. Philosophical Transactions of the Royal Society London B, 366, 2035-2044. doi:10.1098/ rstb.2010.0411.

Mistretta, P. A. (2002). Managing for forest health. Journal of Forestry, 100, 24-27.

Moore, J. L., Rout, T. M., Hauser, C. E., Moro, D., Jones, M., Wilcox, C., et al. (2010). Protecting islands from pest invasion: optimal allocation of biosecurity resources between quarantine and surveillance. Biological Conservation, 143, 1068-1078. doi:10.1016/j.biocon.2010.01.019.

Moricca, S., \& Ragazzi, A. (2009). Lusus naturae: cambiamenti climatici ed invasioni di parassiti vegetali modificano il territorio agro-forestale. Rivista Italiana di Agronomia, 3, S13-S17.

Moslonka-Lefebvre, M., Finley, A., Dorigatti, I., DehnenSchmutz, K., Harwood, T., Jeger, M. J., et al. (2011). Networks in plant epidemiology: from genes to landscapes, countries and continents. Phytopathology, 101, 392-403. doi:10.1094/PHYTO-07-10-0192.

Ndeffo Mbah, M. L., Forster, G. A., Wesseler, J. H., \& Gilligan, C. A. (2010). Economically optimal timing for crop disease control under uncertainty: an options approach. Interface, 7, 1421-1428. doi:10.1098/rsif.2010.0056.

Newton, A. C., Johnson, S. N., \& Gregory, P. J. (2011). Implications of climate change for diseases, crop yields and food 
security. Euphytica, 179, 3-18. doi:10.1007/s10681-0110359-4.

Norton, G., \& Taylor, M. (2010). What pest is that? Recent developments in digital pest diagnostics. Outlooks on Pest Management, 21, 236-238. doi:10.1564/21oct11.

O’Halloran, T. L., Law, B. E., Goulden, M. L., Wang, Z., Barr, J. G., Schaaf, C., et al. (2012). Radiative forcing of natural forest disturbances. Global Change Biology, in press doi:10.1111/j.1365-2486.2011.02577.x

Ogden, A. E., \& Innes, J. (2007). Incorporating climate change adaptation considerations into forest management planning in the boreal forest. International Forestry Review, 9, 713733. doi:10.1505/ifor.9.3.713.

Østergård, H., Finckh, M. R., Fontaine, L., Goldringer, I., Hoad, S. P., Kristensen, K., et al. (2009). Time for a shift in crop production: embracing complexity through diversity at all levels. Journal of the Science of Food and Agriculture, 89, 1439-1445. doi:10.1002/jsfa.3615.

Paajanen, R., Julkunen-Tiitto, R., Nybakken, L., Petrelius, M., Tegelberg, R., Pusenius, J., et al. (2011). Dark-leaved willow (Salix myrsinifolia) is resistant to three-factor (elevated $\mathrm{CO}_{2}$, temperature and UV-B-radiation) climate change. New Phytologist, 190, 161-168. doi:10.1111/j.14698137.2010.03583.x.

Paoletti, E., Bytnerowicz, A., Andersen, C., Augustaitis, A., Ferretti, M., Grulke, N., et al. (2007). Impacts of air pollution and climate change on forest ecosystems - emerging research needs. TheScientificWorldJOURNAL, 7, 1-8. doi:10.1100/tsw.2007.52.

Parks, C. G., \& Bernier, P. (2010). Adaptation of forests and forest management to changing climate with emphasis on forest health: a review of science, policies and practices. Forest Ecology and Management, 259, 657-659. doi:10.1016/S0378-1127(09)00903-7.

Paterson, R. R. M., \& Lima, N. (2010). How will climate change affect mycotoxins in food? Food Research International, 43, 1902-1914. doi:10.1016/j.foodres.2009.07.010.

Pautasso, M. (2012). Observed impacts of climate change on terrestrial birds in Europe: an overview. Italian Journal of Zoology, in press doi:10.1080/11250003.2011.627381

Pautasso, M., Holdenrieder, O., \& Stenlid, J. (2005). Susceptibility to fungal pathogens of forests differing in tree diversity. In M. Scherer-Lorenzen, Ch Koerner, \& D. Schulze (Eds.), Forest diversity and function (pp. 263-289). Berlin: Springer. doi:10.1007/3-540-26599-6_13.

Pautasso, M., Dehnen-Schmutz, K., Holdenrieder, O., Pietravalle, S., Salama, N., Jeger, M. J., et al. (2010). Plant health and global change - some implications for landscape management. Biological Reviews, 85, 729-755. doi:10.1111/j.1469185X.2010.00123.x.

Peng, C., Ma, Z., Lei, X., Zhu, Q., Chen, H., Wang, W., et al. (2011). A drought-induced pervasive increase in tree mortality across Canada's boreal forests. Nature Climate Change, 1, 467-471. doi:10.1038/nclimate1293.

Perkins, L. B., Leger, E. A., \& Nowak, R. S. (2011). Invasion triangle: an organizational framework for species invasion. Ecology \& Evolution, 1, 610-625. doi:10.1002/ece3.47.

Petrokofsky, G., Brown, N. D., Hemery, G. E., Woodward, S., Wilson, E., Weatherall, A., et al. (2010). A participatory process for identifying and prioritizing policy-relevant research questions in natural resource management: a case study from the UK forestry sector. Forestry, 83, 357-367. doi:10.1093/forestry/cpq018.

Petter, F., Brunel, S., \& Suffert, M. (2010). Pest risk analysis as applied to plant pathogens. In R. N. Strange \& M. L. Gullino (Eds.), The role of plant pathology in food safety and food security (pp. 137-150). Berlin: Springer. doi:10.1007/978-1-4020-8932-9_12.

Phalan, B., Balmford, A., Green, R. E., \& Scharlemann, J. P. W. (2011). Minimising the harm to biodiversity of producing more food globally. Food Policy, 36, S62-S71. doi:10.1016/j.foodpol.2010.11.008.

Pinkard, E. A., Battaglia, M., Bruce, J., Leriche, A., \& Kriticos, D. J. (2010). Process-based modelling of the severity and impact of foliar pest attack on eucalypt plantation productivity under current and future climates. Forest Ecology and Management, 259, 839-847. doi:10.1016/j. foreco.2009.06.027.

Pritchard, S. G. (2011). Soil organisms and global climate change. Plant Pathology, 60, 82-89. doi:10.1111/j.13653059.2010.02405.x.

Quarles, W. (2007). Global warming means more pests. The IPM Practitioner, 29(9/10), 1-8.

Quijas, S., Schmid, B., \& Balvanera, P. (2010). Plant diversity enhances provision of ecosystem services: a new synthesis. Basic and Applied Ecology, 11, 582-593. doi:10.1016/j. baae.2010.06.009.

Rebaudo, F., \& Dangles, O. (2011). Coupled information diffusion-pest dynamics models predict delayed benefits of farmer cooperation in pest management programs. PLoS Computational Biology, 7, e1002222. doi:10.1371/journal. pcbi. 1002222.

Reganold, J. P., Jackson-Smith, D., Batie, S. S., Harwood, R. R., Kornegay, J. L., Bucks, D., et al. (2011). Transforming U. S. agriculture. Science, 332, 670-671. doi:10.1126/ science.1202462.

Régnière, J. (2012). Invasive species, climate change and forest health. In T. Schlichter \& L. Montes (Eds.), Forests in development: a vital balance (pp. 27-37). Berlin: Springer. doi:10.1007/978-94-007-2576-8_3.

Rizzo, D. M., Meentemeyer, R. K., \& Garbelotto, M. (2011). The emergence of Phytophthora ramorum in North America and Europe. In L. A. Olsen, D. A. Relman, E. R. Choffnes, \& L. Pray (Eds.), Fungal diseases: an emerging challenge to human, animal and plant health (pp. 312324). Washington, DC: Institute of Medicine of the National Academies.

Robinet, C., Van Opstal, N., Baker, R., \& Roques, A. (2011). Applying a spread model to identify the entry points from which the pine wood nematode, the vector of pine wilt disease, would spread most rapidly across Europe. Biological Invasions, 13, 2981-2995. doi:10.1007/s10530-0119983-0.

Rohr, J. R., Dobson, A. P., Johnson, P. T. J., Kilpatrick, A. M., Paull, S. H., Raffel, T. R., et al. (2011). Frontiers in climate change-disease research. Trends in Ecology \& Evolution, 26, 270-277. doi:10.1016/j.tree.2011.03.002.

Rohrs-Richey, J. K., Mulder, C. P. H., Winton, L. M., \& Stanosz, G. (2011). Physiological performance of an Alaskan shrub (Alnus fruticosa) in response to disease (Valsa melanodiscus) and water stress. New Phytologist, 189, 295-307. doi:10.1111/j.1469-8137.2010.03472.x. 
Roos, J., Hopkins, R., Kvarnheden, A., \& Dixelius, C. (2010). The impact of global warming on plant diseases and insect vectors in Sweden. European Journal of Plant Pathology, 129, 9-19. doi:10.1007/s10658-010-9692-z.

Rosenzweig, C., Iglesias, A., Yang, X. B., Epstein, P. R., \& Chivian, E. (2001). Climate change and extreme weather events. Implications for food production, plant diseases, and pests. Global Change \& Human Health, 2, 90-104. doi:10.1023/A:1015086831467.

Roy, B. A., Güsewell, S., \& Harte, J. (2004). Response of plant pathogens and herbivores to a warming experiment. Ecology, 85, 2570-2581. doi:10.1890/03-0182.

Rytkönen, A., Lilja, A., Drenkhan, R., Gaitnieks, T., \& Hantula, J. (2011). First record of Chalara fraxinea in Finland and genetic variation among isolates sampled from Åland, mainland Finland, Estonia and Latvia. Forest Pathology, 41, 169-174. doi:10.1111/j.1439-0329.2010.00647.x.

Salinari, F., Giosue, S., Tubiello, F. N., Rettori, A., Rossi, V., Spanna, F., et al. (2006). Downy mildew (Plasmopara viticola) epidemics on grapevine under climate change. Global Change Biology, 12, 1299-1307. doi:10.1111/ j.1365-2486.2006.01175.x.

Savary, S., Mila, A., Willocquet, L., Esker, P., Carisse, O., \& McRoberts, N. (2011a). Risk factors for crop health under global change and agricultural shifts: a framework of analyses using rice in tropical and subtropical Asia as a model. Phytopathology, 101, 696-709. doi:10.1094/PHYTO-07-100183.

Savary, S., Nelson, A., Sparks, A. H., Willocquet, L., Duveiller, E., Mahuku, G., et al. (2011b). International agricultural research tackling the effects of global and climate changes on plant diseases in the developing world. Plant Disease, 95, 1204-1216. doi:10.1094/PDIS-04-11-0316.

Scherm, H. (2004). Climate change: can we predict the impacts on plant pathology and pest management? Canadian Journal of Plant Pathology, 26, 267-273. doi:10.1080/ 07060660409507143.

Seem, R. C. (2004). Forecasting plant disease in a changing climate: a question of scale. Canadian Journal of Plant Pathology, 26, 274-283. doi:10.1080/07060660409507144.

Seidl, R., Fernandes, P. M., Fonseca, T. F., Gillet, F., Jönssong, A. M., Merganičová, K., et al. (2011). Modelling natural disturbances in forest ecosystems: a review. Ecological Modelling, 222, 903-924. doi:10.1016/j.ecolmodel.2010.09.040.

Shaw, M.W. (2009). Preparing for changes in plant diseases due to climate change. Plant Protection Science, 45, S3-S10. http://journals.uzpi.cz/uniqueFiles/13961.pdf

Shaw, M. W., \& Osborne, T. M. (2011). Geographic distribution of plant pathogens in response to climate change. Plant Pathology, 60, 31-43. doi:10.1111/j.1365-3059.2010.02407.x.

Siebold, M., \& von Tiedemann, A. (2012). Potential effects of global warming on oilseed rape pathogens in Northern Germany. Fungal Ecology, 5, 62-72. doi:10.1016/j. funeco.2011.04.003.

Singh, B. K., Bardgett, R. D., Smith, P., \& Reay, D. S. (2010). Microorganisms and climate change: terrestrial feedbacks and mitigation options. Nature Reviews Microbiology, 8, 779-790. doi:10.1038/nrmicro2439.

Skelsey, P., Rossing, W. A. H., Kessel, G. J. T., \& van der Werf, W. (2010). Invasion of Phytophthora infestans at the landscape level: how do spatial scale and weather modulate the consequences of spatial heterogeneity in host resistance? Phytopathology, 100, 1146-1161. doi:10.1094/PHYTO06-09-0148.

Steingröver, E. G., Geertsema, W., \& van Wingerden, W. K. R. E. (2010). Designing agricultural landscapes for natural pest control: a transdisciplinary approach in the Hoeksche Waard (The Netherlands). Landscape Ecology, 25, 825838. doi:10.1007/s10980-010-9489-7.

Stenlid, J., Oliva, J., Boberg, J. B., \& Hopkins, A. J. M. (2011). Emerging diseases in European forest ecosystems and responses in society. Forests, 2, 486-504. doi:10.3390/ f2020486.

Sturrock, R. N., Frankel, S. J., Brown, A. V., Hennon, P. E., Kliejunas, J. T., Lewis, K. E., et al. (2011). Climate change and forest diseases. Plant Pathology, 60, 133-149. doi:10.1111/j.1365-3059.2010.02406.x.

Sutherst, R. W., Constable, F., Finlay, K. J., Harrington, R., Luck, J., \& Zalucki, M. P. (2011). Adapting to crop pest and pathogen risks under a changing climate. Wiley Interdisciplinary Reviews - Climate Change, 2, 220-237. doi:10.1002/wcc.102.

Teixeira, E. I., Fischer, G., van Velthuizen, H., Walter, C., \& Ewert, F. (2012). Global hot-spots of heat stress on agricultural crops due to climate change. Agricultural and Forest Meteorology, in press doi:10.1016/j.agrformet.2011.09.002

Thomas, K. (2010). Climate change and management of cool season grain legume crops. In S. S. Yadav, D. L. McNeil, R. Redden, \& S. A. Patil (Eds.), Impact of climate change on diseases of cool season grain legume crops (pp. 99113). Berlin: Springer. doi:10.1007/978-90-481-3709-1_6.

Thompson, S., Alvarez-Loayza, P., Terborgh, J., \& Katul, G. (2010). The effects of plant pathogens on tree recruitment in the Western Amazon under a projected future climate: a dynamical systems analysis. Journal of Ecology, 98, 14341446. doi:10.1111/j.1365-2745.2010.01726.x.

Tomback, D. F., \& Achuff, P. (2010). Blister rust and western forest biodiversity: ecology, values and outlook for white pines. Forest Pathology, 40, 186-225. doi:10.1111/j.14390329.2010.00655.x.

Truscott, J. E., \& Gilligan, C. A. (2003). Response to a deterministic epidemiological system to a stochastically varying environment. Proceedings of the National Academy of Sciences USA, 100, 9067-9072. doi:10.1073/pnas.1436273100.

Tsui, C. K. M., Roe, A. D., El-Kassaby, Y. A., Rice, A. R., Alamouti, S. M., Sperling, F. A. H., et al. (2012). Population structure and migration pattern of a conifer pathogen, Grosmannia clavigera, as influenced by its symbiont, the mountain pine beetle. Molecular Ecology, 21, 71-86. doi:10.1111/j.1365-294X.2011.05366.x.

Tubby, K. V., \& Webber, J. F. (2010). Pests and diseases threatening urban trees under a changing climate. Forestry, 83, 451-459. doi:10.1093/forestry/cpq027.

Tylianakis, J. M., Didham, R. K., Bascompte, J., \& Wardle, D. A. (2008). Global change and species interactions in terrestrial ecosystems. Ecology Letters, 11, 1351-1363. doi:10.1111/j.1461-0248.2008.01250.x.

Venette, R. C. (2009). Implication of global climate change on the distribution and activity of Phytophthora ramorum. In: K. McManus, \& K. W. Gottschalk (Eds.) Proceedings 20th U.S. Department of Agriculture interagency research forum on invasive species 2009 (pp. 58-59.) USDA FS, GTR NRS-P-51. 
Venette, R. C., Kriticos, D. J., Magarey, R. D., Koch, F. H., Baker, R. H. A., Worner, S. P., et al. (2010). Pest risk maps for invasive alien species: a roadmap for improvement. BioScience, 60, 349-362. doi:10.1525/bio.2010.60.5.5.

Vettraino, A. M., Brasier, C. M., Brown, A. V., \& Vannini, A. (2011). Phytophthora himalsilva sp. nov. an unusually phenotypically variable species from a remote forest in Nepal. Fungal Biology, 115, 275-287. doi:10.1016/j. funbio.2010.12.013.

Walther, G.-R., Post, E., Convey, P., Menzel, A., Parmesan, C., Beebee, T. J. C., et al. (2002). Ecological responses to recent climate change. Nature, 416, 389-395. doi:10.1038/416389a.

Watt, M. S., Stone, J. K., Hood, I. A., \& Palmer, D. J. (2010). Predicting the severity of Swiss needle cast on Douglas-fir under current and future climate in New Zealand. Forest Ecology and Management, 260, 2232-2240. doi:10.1016/j. foreco.2010.09.034.

Watt, M. S., Ganley, R. J., Kriticos, D. J., \& Manning, L. K. (2011). Dothistroma needle blight and pitch canker: the current and future potential distribution of two important diseases of Pinus species. Canadian Journal of Forest Research, 41, 412-424. doi:10.1139/X10-204.

Webber, J. (2010). Pest risk analysis and invasion pathways for plant pathogens. New Zealand Journal of Forestry Science, 40, S45-S56.

West, J. S., Holdgate, S., Townsend, J. A., Edwards, S. G., Jennings, P., \& Fitt, B. D. L. (2012). Impacts of changing climate and agronomic factors on fusarium ear blight of wheat in the UK. Fungal Ecology, 5, 53-61. doi:10.1016/j. funeco.2011.03.003.

Wingfield, M. J., Slippers, B., \& Wingfield, B. D. (2010). Novel associations between pathogens, insects and tree species threaten world forests. New Zealand Journal of Forestry Science, 40, 95-103.

Witzell, J., Berglund, M., \& Rönnberg, J. (2011). Does temperature regime govern the establishment of Heterobasidion annosum in Scandinavia? International Journal of Biometeorology, 55, 275-284. doi:10.1007/s00484-010-0333-1.

Woods, A. (2011). Is the health of British Columbia's forests being influenced by climate change? If so, was this predictable? Canadian Journal of Plant Pathology, 33, 117-126. doi:10.1080/07060661.2011.563908.

Woods, A. J., Heppner, D., Kope, H. H., Burleigh, J., \& Maclauchlan, L. (2010). Forest health and climate change: a British Columbia perspective. The Forestry Chronicle, 86, 412-422.

Xu, X. M., Harwood, T. D., Pautasso, M., \& Jeger, M. J. (2009). Spatio-temporal analysis of an invasive plant pathogen (Phytophthora ramorum) in England and Wales. Ecography, 32, 504-516. doi:10.1111/j.1600-0587.2008.05597.x.

Xu, X. M., Jeffries, P., Pautasso, M., \& Jeger, M. J. (2011). Combined use of biocontrol agents to manage plant diseases in theory and practice: a review. Phytopathology, 101, 1024-1031. doi:10.1094/PHYTO-08-10-0216.

Yemshanov, D., McKenney, D. W., Pedlar, J. H., Koch, F. H., \& Cook, D. (2009). Towards an integrated approach to modelling the risks and impacts of invasive forest species. Environmental Reviews, 17, 163-178. doi:10.1139/A09007.

Yousefpour, R., Jacobsen, J. B., Thorsen, B. J., Meilby, H., Hanewinkel, M., \& Oehler, K. (2012) A review of decision-making approaches to handle uncertainty and risk in adaptive forest management under climate change. Annals of Forest Science, in press doi:10.1007/s13595-0110153-4

Zhu, Y., Chen, H., Fan, J., Wang, Y., Li, Y., Chen, J., et al. (2000). Genetic diversity and disease control in rice. $\mathrm{Na}$ ture, 406, 718-722. doi:10.1038/35021046.

Ziska, L. H., \& Runion, G. B. (2007). Future weed, pest, and disease problems for plants. In P. C. D. Newton, R. A. Carran, G. R. Edwards, \& P. A. Niklaus (Eds.), Agroecosystems in a changing climate (pp. 261-287). Boca Raton: CRC Press.

Zocca, A., Zanini, C., Aimi, A., Frigimelica, G., La Porta, N., \& Battisti, A. (2008). Spread of plant pathogens and insect vectors at the northern range margin of cypress in Italy. Acta Oecologica, 33, 307-313. doi:10.1016/j.actao.2008.01.004.

Zvereva, E. L., \& Kozlov, M. V. (2006). Consequences of simultaneous elevation of carbon dioxide and temperature for plant-herbivore interactions: a meta-analysis. Global Change Biology, 12, 27-41. doi:10.1111/j.1365-2486.2005.01086.x. 